\title{
Therapeutic approaches for tumor necrosis factor inhibition
}

\author{
Maria Letícia de Castro Barbosa ${ }^{1,2}$, Milla Machado Fumian ${ }^{1,3}$, Ana Luísa Palhares de Miranda ${ }^{1,3}$, \\ Eliezer J. Barreiro ${ }^{1,2,3}$, Lídia Moreira Lima ${ }^{1,2,3, *}$
}

\author{
${ }^{1}$ LASSBio, Laboratory of Evaluation and Synthesis of Bioactive Substances, Faculty of Pharmacy, \\ Federal University of Rio de Janeiro, ${ }^{2}$ Chemistry Institute, Federal University of Rio de Janeiro, \\ ${ }^{3}$ Institute of Biomedical Sciences, Federal University of Rio de Janeiro
}

\begin{abstract}
Tumor necrosis factor (TNF) consists of an inflammatory cytokine essential for homeostasis and organism defense. Despite its physiological relevance, both increased biosynthesis and release of TNF lead to the exacerbation of inflammatory and oxidative responses, which are related to the pathogenesis of a host of diseases of an inflammatory, autoimmune and/or infectious nature. In this context, effective therapeutic approaches for the modulation of TNF have been the focus of research efforts. Approximately one million individuals worldwide have been treated with biotechnological inhibitors of this cytokine, the so-called anti-TNF biopharmaceuticals. However, given the high risk of infection and the limitations related to cost and administration routes, new therapeutic approaches aimed at biological targets that directly or indirectly modulate the production and/or activation of TNF appear promising alternatives for the discovery of new anti-inflammatory and immunomodulatory orally active drugs and are therefore discussed in this paper.
\end{abstract}

Uniterms: Tumor necrosis factor. TACE. p38 MAPK. NF-кB. cAMP. Phosphodiesterase. Adenosine receptor.

\begin{abstract}
O fator de necrose tumoral (do inglês, tumor necrosis factor - TNF) consiste em uma citocina inflamatória essencial para a homeostase e defesa do organismo. A despeito de sua relevância fisiológica, o aumento da biossíntese e liberação do TNF conduzem à exacerbação das respostas inflamatória e oxidativa, as quais estão relacionadas à patogênese de várias doenças de natureza inflamatória, auto-imune e/ou infecciosa. A busca por abordagens terapêuticas eficientes na modulação do TNF tem sido alvo de diversos esforços de pesquisa. Aproximadamente um milhão de pessoas ao redor do mundo já foi tratado com inibidores biotecnológicos desta citocina, os chamados biofármacos anti-TNF. Entretanto, em face ao elevado risco de infecções e as limitações relacionadas ao custo e a via de administração, novas abordagens terapêuticas com foco em alvos que modulem, de forma direta ou indireta, a produção e/ou ativação do TNF surgem como alternativas promissoras para a descoberta de novos fármacos antiinflamatórios e imunomoduladores ativos por via oral e serão discutidas neste trabalho.
\end{abstract}

Unitermos: Fator de necrose tumoral. TACE. MAPK p38. NF-кB. AMPc. Fosfodiesterase. Receptor de adenosina.

\section{INTRODUCTION}

The functioning of the immune system is finely modulated by the activity of cytokines, pro- and antiinflammatory mediators (Palladino et al., 2003). Imbalances in this system can lead to the development of chronic

*Correspondence: L. M. Lima. LASSBio - Laboratório de Avaliação e Síntese de Substâncias Bioativas, Centro de Ciências da Saúde, Faculdade de Farmácia, Universidade Federal do Rio de Janeiro - UFRJ, Ilha do Fundão. Caixa Postal 68024 - 21944-970 - Rio de Janeiro - RJ, Brazil. E-mail: lidia@pharma.ufrj.br inflammatory conditions, autoimmune diseases and increased susceptibility and/or non-resolution of infections (Hanada, Yoshimura, 2002). In immune-mediated inflammatory disorders (IMIDs), the immune system becomes imbalanced thereby preventing healing of inflammation, which consequently evolves and promotes tissue damage (Lin et al., 2008).

Therapeutic approaches currently used to treat these disorders focus predominantly on suppressing the production of pro-inflammatory mediators and on the inhibition 
of immune response triggering, by using for instance, the modulation of cytokine signaling pathways as a strategy (Hanada,Yoshimura, 2002).

The use of modulators of the production and biological activity of tumor necrosis factor alpha (TNF- $\alpha$ ) in particular has been widely described and discussed in the literature (Lin et al., 2008), since the increased tissue and/or plasma concentration of this cytokine is associated with the establishment and development of several diseases with diverse causes. These diseases can stem from: (a) an autoimmune origin - e.g. Crohn's disease, diabetes, psoriasis, rheumatoid arthritis and systemic lupus erythematosus; (b) an infectious origin - e.g. hepatitis C, acquired immunodeficiency syndrome (AIDS), septic shock, erythema nodosum leprosum; and (c) a tumor e.g. multiple myeloma and ovarian cancer (Marriot et al., 1997; Sampaio et al., 2002; Palladino et al., 2003; Steinwurz, 2003; Sirohi, Powles, 2004; Paul et al., 2006; DasGupta et al., 2009).

\section{Tumor necrosis factor}

Tumor necrosis factor (TNF) consists of a pleiotropic cytokine, regulating various cellular and biological events, such as immune and inflammatory responses, cell differentiation and proliferation, apoptosis and energy metabolism (Cawthorne, Sethi, 2008). TNF was originally identified as a substance present in the serum of animals treated with bacterial lipopolysaccharide (LPS), resulting in necrosis of tumors in vivo (Palladino et al., 2003; Paul et al., 2006).

Two types of tumor necrosis factor are currently known: TNF- $\alpha$ and TNF- $\beta$ (or lymphotoxin), which present a striking similarity in their three-dimensional structures, despite the low sequence homology (ca.33\%) found in the primary structure of their proteins (Gray et al., 1984; Pennica et al., 1984; Banner et al., 1993). The activities of the cytokines TNF- $\alpha$ and TNF- $\beta$ are also very similar, both in vitro and in vivo, although they are antigenically distinct (Sack, 2002).

TNF- $\alpha$ is the most extensively studied cytokine and its main sources in vivo are activated monocytes, fibroblasts and endothelial cells. Macrophages, T cells, B lymphocytes, granulocytes, smooth muscle cells, eosinophils, chondrocytes, osteoblasts, mast cells, glial cells and keratinocytes also produce TNF- $\alpha$ after stimulation (Mukhopadhyay et al., 2006).

LPS is the most potent stimulus triggering the biosynthesis of TNF- $\alpha$ by mononuclear phagocytes enabling large quantities of this cytokine to be released in infections by gram-negative bacteria. Other mediators induce its production in different cell types, including interleukin-1
(IL-1), platelet derived growth factor (PDGF), oncostatin $M$, interferon- $\beta$ (IFN- $\beta$ ), and the TNF- $\alpha$ itself, which can stimulate or inhibit its own synthesis, depending on the cell type (Mukhopadhyay et al., 2006).

The production of TNF- $\alpha$ begins with the adhesion of a ligand (which usually consists of a microbial component) to a pattern recognition receptor (PRR) - the toll-like receptor (TLR), for example. This type of receptor is then able to recognize pathogen-associated molecular patterns (PAMPs), starting a cascade of signal transduction leading to the activation of transcription factors, such as the NFкB (nuclear factor kappa B) (Zuany-Amorin et al., 2002; Lima et al., 2006).

The NF- $\kappa \mathrm{B}$ is present in the cytoplasm associated with the inhibitory protein I $\mathrm{K} \mathrm{B} \alpha$. Activation of the $\mathrm{NF}-\kappa \mathrm{B}$ signaling pathway leads to phosphorylation and polyubiquitination of the protein I $\mathrm{B} \alpha$ and its subsequent degradation by the $26 \mathrm{~S}$ proteasome. The degradation of this inhibitory protein releases the NF- $\mathrm{KB}$ dimer for translocation to the nucleus, inducing the transcription of several genes associated with the inflammatory response, including those encoding the cytokine TNF- $\alpha$ (Keifer et al., 2001; Suryaprasad, Prindiville, 2003).

The human TNF- $\alpha$ is synthesized as a polypeptide precursor of 233 amino acid residues attached to the cell membrane and is released through regiospecific proteolysis between the amino acids Ala76 and Val77, producing the soluble form of the cytokine (Gearing et al., 1994; Lima et al., 2006; Mukhopadhyay et al., 2006; DasGupta et al., 2009). The enzyme responsible for the proteolytic cleavage of TNF- $\alpha$ anchored to the cell membrane was identified as a zinc-dependent metalloproteinase, denoted as tumor necrosis factor alpha converting enzyme (TACE) (Black et al., 1997; Moss et al., 1997). Cells derived from TACE knockout mice showed approximately $90 \%$ reduction in TNF- $\alpha$ release (Mohan et al., 2002).

Both forms of TNF- $\alpha$, the soluble form and the form associated with the cell membrane, trigger biological effects and metabolic responses, although the specific functions of each remain controversial (Palladino et al., 2003; Cawthorne, Sethi, 2008; Taylor, 2010).

TNF- $\alpha$ exerts its multiple biological effects by interacting with two structural and functionally different receptors: the TNF receptor type I (TNF-RI, also known as p60, p55 or CD120a) and the TNF receptor type II (TNF-RII also known as p80, p75 or CD120b) (Paul et al., 2006). Both receptors are transmembrane glycoproteins containing sequences of six cysteine residues that are repeated four times in their $\mathrm{N}$-terminal extracellular domain (Banner et al., 1993). Although the extracellular domains are remarkably similar, the intracellular domains of TNF 
receptors are significantly different, activating overlapping and distinct signaling pathways (Palladino et al., 2003; DasGupta et al., 2009).

All human nucleated cells express TNF receptors, although their distribution varies according to cell type (Palladino et al., 2003). TNF-RI is constitutively expressed in most cells, but not in inactive T cells and erythrocytes; TNF-RII is expressed more often in hematopoietic and endothelial cells (Lima et al., 2006).

Efforts have been directed towards the elucidation of the specific physiological role of TNF receptors TNF-RI and TNF-RII, using, among other tools, knockout mice and monoclonal antibodies directed at the antigenically distinct receptors, acting as agonists.

The use of agonists has demonstrated that the activation of TNF-RI is sufficient to mimic the biological effects of TNF- $\alpha$ in several cell compartments (Tartaglia et al., 1993; Horssen et al., 2006; DasGupta et al., 2009). Additionally, studies employing TNF-RI knockout mice have shown that these animals were resistant to LPS-induced liver injury, in which TNF- $\alpha$ plays a significant role by inducing hepatic apoptosis (Shimizu et al., 2005). The lung inflammatory response in TNF-RI knockout mice after pulmonary challenge with Micropolyspora faeni antigen or LPS was also significantly reduced (Smith et al., 1998).

The binding of TNF- $\alpha$ to the TNF-RI receptor triggers a cascade of events involving the activation of a series of serine/threonine protein kinases known as mitogen-activated protein kinases (MAPKs) (Paul et al., 2006). The MAPK signaling cascade follows a sequence of phosphorylation and dephosphorylation reactions, starting with the activation of a MAPK kinase kinase (MAPKKK), which activates a MAPK kinase (MAPKK), which ultimately leads to the activation of specific MAPKs, e.g. p38 MAPK. The activated p38 MAPK phosphorylates other kinases and transcription factors, leading to the gene expression of cytokines and growth factors (Roux, Blenis, 2004; Mutalik, Venkatesh, 2006).

Another central event in the binding of TNF- $\alpha$ to the TNF-RI is the activation of the nuclear factor NF- $\kappa B$. This interaction activates, via the TRADD domain (tumor necrosis factor receptor- 1 associated death domain), the IKK complex (inhibitor of nuclear factor- $\kappa \mathrm{B}$ kinase kinase), which is responsible for triggering the degradation process of the inhibitory protein I $\mathrm{B} \alpha$. Once activated, the IKK complex phosphorylates $I \kappa B \alpha$, resulting in the release of $\mathrm{NF}-\mathrm{\kappa B}$ for translocation to the nucleus, and consequently, in the expression of genes encoding cytokines, chemokines and proteases (Paul et al., 2006).

Both TNF-RI and TNF-RII receptors can be cleaved from the cell surface by members of the matrix metallo- proteinases family in response to inflammatory stimuli. The extracellular domains released through the proteolytic cleavage process retain the ability to bind to TNF, becoming soluble TNF receptors (TNF-Rs) (Brakebusch et al., 1994; Palladino et al., 2003).

The soluble receptors compete with membrane receptors for the binding of agonists TNF- $\alpha$ and TNF- $\beta$, acting as endogenous inhibitors of cytokine activity. This behavior allows modulation and homeostatic regulation of TNF activity in the body (Brakebusch et al., 1994).

TNF- $\alpha$ is a versatile cytokine that alters tissue remodeling, increases epithelial cell barrier permeability, induces macrophages activation, recruitment of inflammatory cells and expression of adhesion molecules. TNF- $\alpha$ also plays a crucial role in the development, homeostasis and adaptive immune response (Suryaprasad, Prindiville, 2003).

On the other hand, despite the physiological relevance of this cytokine, it is known that the increase of its biosynthesis and release leads to exacerbation of inflammatory and oxidative responses, which are related to the pathogenesis of a wide range of diseases, e.g. rheumatoid arthritis, psoriasis, Crohn's disease, erythema nodosum leprosum and multiple myeloma (Hashimoto, 2002; Mukhopadhyay et al., 2006; Lin et al., 2008).

\section{Therapeutic strategies for TNF inhibition}

The search for effective therapeutic approaches in the modulation of TNF- $\alpha$ has been the focus of research efforts. Approximately one million individuals worldwide are either undergoing treatment or have been treated with TNF inhibitors available in the pharmaceutical market, encompassing indications that include rheumatoid arthritis, psoriatic arthritis, psoriasis and inflammatory bowel diseases, in addition to numerous potential clinical applications which are currently in various stages of evaluation (Suryaprasad, Prindiville, 2003; Feldmann et al., 2005; Hochberg et al., 2005, Lin et al., 2008).

Several drugs commonly used as immunosuppressants, e.g. cyclosporine A (1) and dexamethasone (2), exhibit TNF- $\alpha$ modulation, although their effects are associated with considerable toxicity. However, as the mechanisms that involve the production of TNF and its activity on cells become better understood, more specific strategies for the inhibition of this cytokine emerge. Examples include the development of new therapeutic agents and the modification of existing ones, seeking lower toxicity, greater potency and a larger number of clinical alternatives (Marriot et al., 1997).

Therapeutic approaches for TNF- $\alpha$ inhibition include neutralizing antibodies and soluble receptors of TNF- $\alpha$, 
which act as inhibitors of surface receptor occupancy; TACE inhibitors; and compounds structurally related to thalidomide (3), the first drug described as a modulator of the biosynthesis of this cytokine. Moreover, strategies for the modulation of signaling pathways involved in the production and biological responses promoted by TNF- $\alpha$ are also known and include some classes of therapeutic agents, such as protein kinase inhibitors (e.g. p38 MAPK inhibitors); modulators of NF- $\mathrm{KB}$ signaling pathway; and regulators of intracellular levels of cyclic adenosine-3',5'monophosphate (cAMP) (DasGupta et al., 2009).

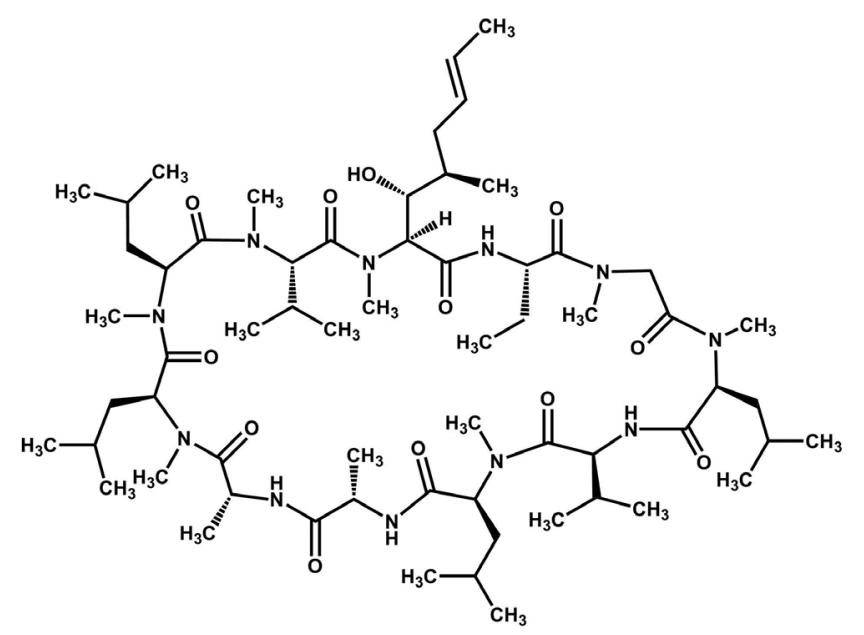

(1) Cyclosporin A
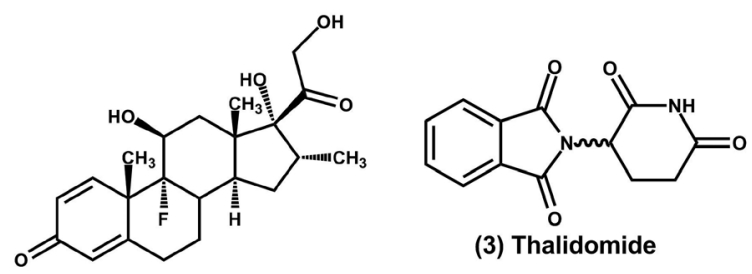

(2) Dexamethasone

\section{Inhibitors of TNF receptor occupancy}

The introduction of biological therapies for inhibition of the pro-inflammatory cytokine TNF- $\alpha$ in the global pharmaceutical market was responsible for a revolution in the treatment of diseases such as rheumatoid arthritis, psoriasis and Crohn's disease (Hochberg et al., 2005; Pappas et al., 2009).

The first two biotech drugs identified were infliximab (Remicade ${ }^{\circledR}$ - Centocor/Schering-Plough) and etanercept (Enbrel ${ }^{\circledR}$ - Amgen/Wyeth) (Table I). Infliximab is a chimeric monoclonal antibody ( $\mathrm{mAb}$ ) of approximately $149 \mathrm{kDa}$ that binds specifically to TNF- $\alpha$ (but not TNF- $\beta$ ) with high affinity, neutralizing its biological activity by inhibiting its binding to the receptors TNF-RI and TNFRII. Etanercept is the product of fusion of a dimeric protein of approximately $150 \mathrm{kDa}$ (IgG1) with the soluble receptor of TNF. These features allow etanercept to bind to both TNF- $\alpha$ and TNF- $\beta$ (Hochberg et al., 2005; Pappas et al., 2009). These biopharmaceuticals were approved for the treatment of rheumatoid arthritis in the late 1990s. Their use was later extended to include other disorders of autoimmune origin, including psoriatic arthritis (Pappas et al., 2009).

The third biotech drug described was adalimumab (Humira ${ }^{\circledR}$ - Abbott), a recombinant human IgG1 monoclonal antibody of approximately $148 \mathrm{kDa}$ specific for human TNF- $\alpha$. Akin to infliximab, adalimumab does not neutralize TNF- $\beta$. In 2002, this biotech drug was introduced in the pharmaceutical market for the treatment of rheumatoid arthritis and its use was also recently approved for the treatment of other immune-inflammatory disorders (Table 1) (Hochberg et al., 2005; Pappas et al., 2009).

The fourth biopharmaceutical identified was certolizumab pegol (Cimzia ${ }^{\circledR}$ - UCB), a humanized antibody fragment specific for TNF- $\alpha$ linked to polyethylene glycol. In 2008, this biological therapy was approved for the treatment of Crohn's disease and, in May 2009, for the treatment of rheumatoid arthritis (Table I) (Tracey et al., 2008; Pappas et al., 2009).

The use of a new biotechnology drug, golimumab (Simponi ${ }^{\circledR}$ - Centocor Ortho Biotech), which consists

TABLE I - TNF inhibitors licensed for clinical use

\begin{tabular}{lcccc}
\hline Brand name & TNF inhibitor & Year & Disease indications $^{\mathrm{a}}$ & Administration route \\
\hline Remicade & Infliximab & 1998 & RA, AS, PsA, psoriasis, CD, UC & i.v. \\
Enbrel & Etanercept & 1999 & RA, JCA, AS, PsA, psoriasis & s.c. \\
Humira & Adalimumab & 2002 & RA, AS, PsA, CD, psoriasis & s.c. \\
Cimzia & Certolizumab pegol & 2008 & CD, AR & s.c. \\
Simponi & Golimumab & 2009 & PsA, AR & s.c. \\
\hline
\end{tabular}

AS: ankylosing spondylitis; CD: Crohn's disease; JCA: juvenile chronic arthritis; PsA: psoriatic arthritis; RA: rheumatoid arthritis; UC: ulcerative colitis.

${ }^{a}$ : Indications approved by United States - Food and Drug Administration (US-FDA). 
of a chimeric immunoglobulin $\mathrm{G}(\mathrm{G} 1 \kappa \mathrm{mAb})$ specific for human TNF, was recently approved by the United States - Food and Drug Administration (US-FDA). This biopharmaceutical binds to both bioactive forms of TNF, i.e. transmembrane and soluble, thus preventing the binding of this cytokine to its receptor target. In April 2009, golimumab was approved for the treatment of rheumatoid arthritis and psoriatic arthritis (Table I) (Tracey et al., 2008; Pappas et al., 2009).

The use of biotech drugs for the treatment of autoimmune diseases leads to fast control of inflammation, resulting in an improvement in terms of function and structural repair of tissues. However, the benefit related to the use of these drugs should be evaluated by also taking into account the potential adverse effects associated with them (Suryaprasad, Prindiville, 2003).

Clinical studies have described the occurrence of infections, lymphoproliferative and neurological disorders, autoimmune reactions and cardiac effects as recurring adverse events related to the continued use of biotech TNF modulators. The development of infection is notably the most common complication associated with anti-TNF- $\alpha$ biological therapy. The most commonly observed infections are in urinary and respiratory tracts (e.g. sinusitis, pharyngitis and bronchitis) (Suryaprasad, Prindiville, 2003; Hochberg et al., 2005; Lin et al., 2007).

The differences in the efficacy and safety of biopharmaceutical TNF- $\alpha$ inhibitors approved for clinical use remain unclear, and therefore the treatment chosen should be guided by expediency based on cost and availability (Pappas et al., 2009).

Recent studies have shown that biological antiTNF- $\alpha$ therapies are more effective when combined with other disease modifying anti-rheumatic drugs (DMARD), particularly methotrexate (4). The reports indicate that the treatment of rheumatoid arthritis with TNF- $\alpha$ biological inhibitors co-administered with methotrexate (4) results in a marked reduction of the disease symptoms and, additionally, this association minimizes the rate of joint destruction more significantly compared to monotherapy with anti-TNF- $\alpha$ biopharmaceuticals (Caporali et al., 2009).

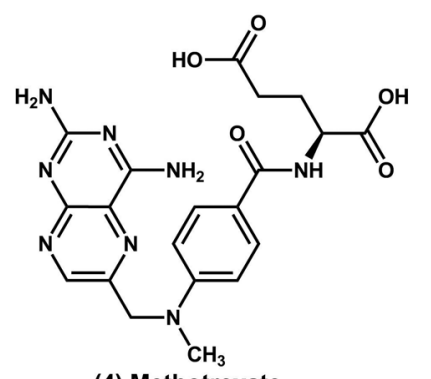

(4) Methotrexate

\section{TACE inhibitors}

From the description of therapeutic benefits related to anti-TNF biological therapy, concerted research effort has been devoted to the development of small molecules capable of inhibiting this cytokine through oral administration (Palladino et al., 2003; Levin et al., 2006; DasGupta et al., 2009).

In this context, the hypothesis that an inhibitor of $\mathrm{TACE}$, i.e. the enzyme responsible for proteolytic cleavage of TNF- $\alpha$ anchored to the cell membrane, would be able to effectively treat several diseases of inflammatory and autoimmune origin by limiting the levels of soluble TNF- $\alpha$, has been strengthened. Based on this objective, several research groups around the world are actively involved in developing small molecules that inhibit TACE (Levin et al., 2006; Kenny, 2007; DasGupta et al., 2009).

Given the similarity between the catalytic domains of TACE and matrix metalloproteinases (MMPs), some previously identified MMP inhibitors, e.g. marimastat (5) and prinomastat (6), were evaluated for their potential inhibitory activity against TACE. Despite showing the expected biological activity, these compounds proved unsuccessful in clinical trials due to adverse effects on skeletal muscle (DasGupta et al., 2009). Even though the exact mechanism responsible for the observed side effects has not been clearly established, some research suggests that the toxicity of these compounds is not linked to the inhibition of TACE, but related to their ability to inhibit MMP-1 and/or MMP-14 (Aranapakam et al., 2003; DasGupta et $a l ., 2009)$. Therefore, the search for new selective inhibitors of TACE devoid of activity on MMPs is underway.

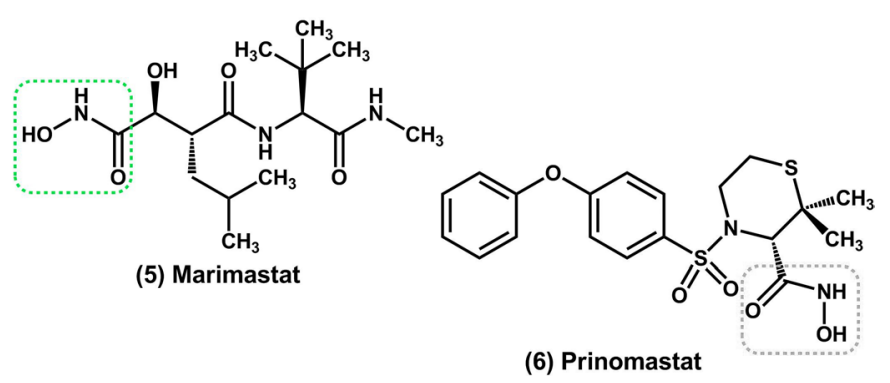

In an attempt to dissociate the inhibitory actions on MMPs and TACE, researchers at Novartis identified the prototypes PKF242-484 (7) and PKF241-466 (8), which presented pronounced anti-inflammatory activity in in vivo models of pulmonary inflammation, and inhibited the release of TNF- $\alpha$ in peripheral blood mononuclear activated cells with $\mathrm{IC}_{50}$ values equal to $56 \mathrm{nM}$ and $141 \mathrm{nM}$, respectively. However, both compounds showed significant inhibitory activity on MMPs 1, 2, 3, 9 and 13, limiting their development potential (Trifilieff et al., 2002). 
Some sulfonamide hydroxamates have also been described as TACE inhibitors (DasGupta et al., 2009). Levin and coworkers, from Wyeth pharmaceutical industry, described the prototype Apratastat (9), commonly known as TMI-05, as a non-selective TACE inhibitor. Compound 9 showed $\mathrm{IC}_{50}$ equal to $20 \mathrm{nM}$ for the inhibition of the enzyme and $\mathrm{ED}_{50}$ equal to $5 \mathrm{mg} / \mathrm{kg}$ (p.o.) for the inhibition of TNF- $\alpha$ release stimulated by LPS in mice. This prototype showed significant anti-inflammatory effect in a model of collagen-induced arthritis in mice (Levin et al., 2006). Although Apratastat (9) was well tolerated in phase I clinical trials, its development was suspended in October 2006 due to lack of efficacy in phase II clinical trials for rheumatoid arthritis (Kenny, 2007).

Worth and coworkers from Roche discovered the ligand Ro-32-7315 (10), a potent TACE inhibitor with 100-fold greater selectivity than most MMPs. Ro-32-7315 (10) has shown high potency in the inhibition of TACE in vitro $\left(\mathrm{IC}_{50}=5.2 \mathrm{nM}\right)$, in the modulation of TNF- $\alpha$ release by different inflammatory cell types, and in controlling the onset of symptoms in animal models of inflammation. Compound $\mathbf{1 0}$ was administered to healthy human volunteers, but its development was eventually discontinued due to limited oral bioavailability (Beck et al., 2002; DasGupta et al., 2009).
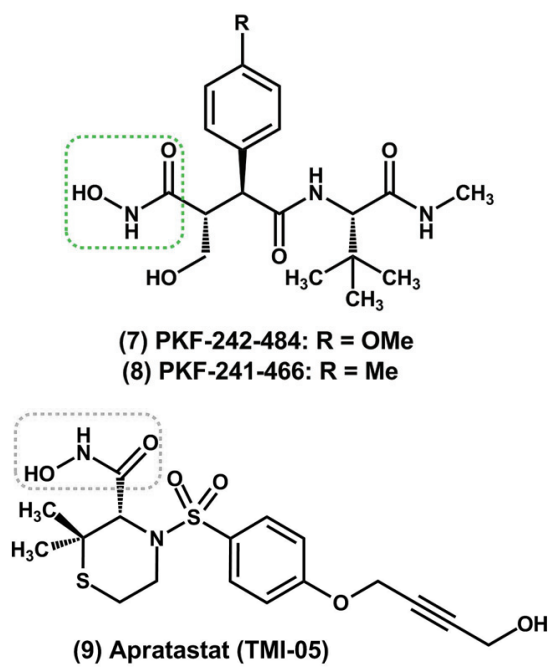

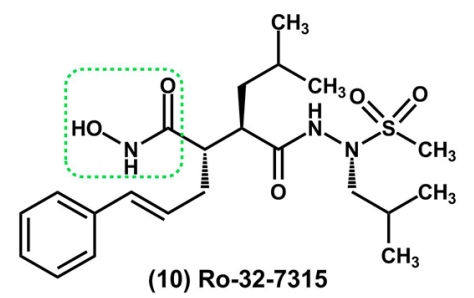

Researchers at Bristol-Myers-Squibb have identified compound $\mathbf{1 1}$ as a selective inhibitor of TACE, with $\mathrm{IC}_{50}$ equal to $3.7 \mathrm{nM}$ for the enzyme inhibition and selectivity in the order of 1,000-fold greater than MMP-1, 2, 9 and 13 (Cherney et al., 2006).

This group of scientists also designed and synthesized a new series of $\gamma$-lactam hydroxamates. The designed compounds exhibited pronounced inhibitory activities in the isolated enzyme, but with low to moderate effect in assays using whole human blood, due to the high rate of binding to plasma proteins. In an attempt to increase the free fraction of compounds, several bioisosters with higher polarity were obtained and tested, most notably IK-682 (12). The $\mathrm{IC}_{50}$ value for 12 was equal to $1 \mathrm{nM}$ in in vitro inhibition of the isolated enzyme and equal to $0.35 \mu \mathrm{M}$ in the whole human blood assay. IK-682 (12) showed selectivity of more than 1,000 times greater compared to most MMPs, and adequate oral bioavailability (Duan et al., 2002; DasGupta et al., 2009).

Changes in the molecular structure of 12 resulted in the design of the prototype BMS-561392 (13), also developed at Bristol-Myers-Squibb. Compound $\mathbf{1 3}$ showed promising inhibitory activity in the release of soluble TNF- $\alpha$ in murine and human blood assays, as well as selectivity of more than 100 times in relation to MMPs. After its oral administration in mice, BMS-561392 (13) inhibited the release of soluble TNF- $\alpha$ induced by LPS with $\mathrm{ED}_{50}$ of $6 \mathrm{mg} / \mathrm{kg}$. In phase I clinical trials, the prototype 13 was well tolerated by healthy human volunteers in a dose range of 15-530 mg, with a half-life of 3-6 hours. However, while BMS-561392 (13) has shown excellent efficacy in phase II clinical trials, these were interrupted
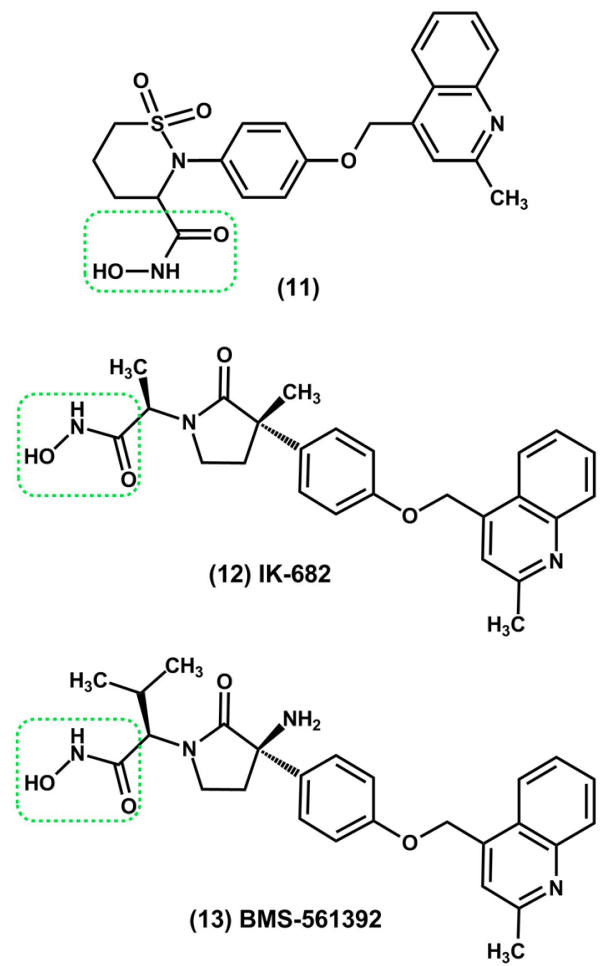
due to the observation of hepatotoxic effects (Qian et al., 2007; DasGupta et al., 2009).

It is worth mentioning that, although the prototypes TMI-05 (9) and BMS-561392 (13) have not been successful in phase II clinical trials, several compounds belonging to different chemical classes have been described as selective inhibitors of TACE, some of which have shown promising results in preclinical tests (DasGupta et al., 2009).

\section{Thalidomide and structural analogues}

Thalidomide (3) (( \pm )2-(2,6-dioxopiperidin-3-yl) isoindoline-1,3-dione) has several pharmacological effects associated with its ability to modulate immune response (Ng et al., 2002; Sampaio et al., 2006). The anti-inflammatory and immunomodulatory properties of $\mathbf{3}$ are due to its ability to inhibit the pro-inflammatory cytokine TNF- $\alpha$. Thalidomide (3) increases the degradation of TNF- $\alpha$ mRNA (Moreira et al., 1993), suppressing the release of this cytokine from different cell types, e.g. monocytes, macrophages, microglia and $\mathrm{T}$ lymphocytes (Sampaio et al., 1991; Peterson et al., 1995; Deng et al., 2003; Kim et al., 2004; Melchert, List, 2007). TNF- $\alpha$ inhibition is largely responsible for the clinical benefits described for 3 in patients with inflammatory and autoimmune diseases, who present exacerbated production of endogenous TNF- $\alpha$ (Corral, Kaplan, 1999).

Many of the pharmacological activities described for thalidomide (3) can be justified by its effects on the NF- $\kappa B$ signaling pathway (Sampaio et al., 2006). Compound 3 blocks NF- $\kappa B$ activation through inhibition of the degradation of inhibitory protein $\mathrm{I} \kappa \mathrm{B} \alpha$, thus preventing the translocation of NF- $\mathrm{kB}$ to the nucleus (Mercurio, Manning, 1999; Palladino et al., 2003; Sampaio et al., 2006). This event is due to the decrease of IKK complex catalytic activity, responsible for the phosphorylation step that triggers the degradation of $\mathrm{I} \kappa \mathrm{B} \alpha$ protein (Keifer et al., 2001).

The identification of the promising anti-inflammatory and immunomodulatory properties of $\mathbf{3}$ resulted in its approval by the US-FDA in July 1998 for the treatment of moderate to severe cutaneous manifestations of lepromatous leprosy (Matthews, McCoy, 2003; Teo et al., 2005; Lima et al., 2006). After approval of thalidomide (3) for the treatment of erythema nodosum leprosum, a series of trials was initiated aimed at evaluating the therapeutic potential of $\mathbf{3}$ in the treatment of inflammatory and autoimmune diseases related to increased plasma concentrations of TNF- $\alpha$, such as rheumatoid arthritis and Crohn's disease (Man et al., 2003; Matthews, McCoy, 2003). More recently, in May 2006, thalidomide (3) was approved by the FDA for the treatment of multiple myeloma (Melchert, List, 2007).
Despite several clinical applications assigned to thalidomide (3), its use is limited to the treatment of diseases for which there are no alternative therapies and is conditioned to the monitoring of neurological effects during treatment and to the use of contraceptive methods in women (Marriott et al., 1997). With this in mind, in a bid to both overcome the inadequate pharmacokinetic profile of $\mathbf{3}$ and reduce its teratogenic and neurotoxic effects, research efforts have been devoted to the search for new analogues with improved pharmacotherapeutic profile (Lima et al., 2002; Man et al., 2003). A number of immunomodulatory derivatives have been reported from chemical changes in the structure of the starting compound, with the goal of generating effective alternatives for the treatment of cancer and immune disorders (Teo et al., 2005).

In this context, Muller and colleagues (1999) described a pronounced increase in the inhibitory activity of TNF- $\alpha$ production in vitro for amino-substituted analogues of thalidomide (3), particularly the 4-amino-phthalimidic derivative (14), being approximately 8,000 times more potent than 3 (Figure 1). Moreover, the authors demonstrated that the substitution of the phthalimidic ring by a functionalized isoindolinone core raised the possibility of four regioisomers (i.e. 16-19, Figure 1). These isoindolinone compounds were designed in an attempt to increase the stability and bioavailability of $\mathbf{3}$. Among them, the 4-aminoisoindolinone analogue (16) was the only one able to significantly inhibit the production of TNF- $\alpha\left(\mathrm{IC}_{50}=100 \mathrm{nM}\right)$, indicating the importance of spatial orientation of the amino group with respect to the carbonyl of isoindolinone core for optimizing anti-TNF activity (Figure 1) (Muller et al., 1999). The derivative 16, named lenalidomide, was approved by the FDA in June 2006 for the treatment of multiple myeloma, and serves as a good example of the usefulness of this strategy (Melchert, List, 2007).

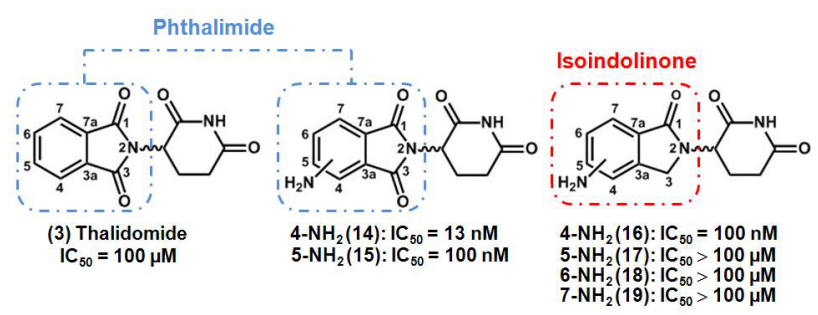

FIGURE 1 - Thalidomide (3) and analogues (14-19) and the inhibition of TNF- $\alpha$ production induced by LPS in human mononuclear cells (Muller et al., 1999).

\section{p38 MAPK inhibitors}

The p38 mitogen-activated protein kinase (p38 MAPK) has received extraordinary attention from the pharmaceutical industry and medicinal chemists since it 
was first described in 1993. It is considered a promising target for therapeutic intervention (Montalban et al., 2008).

This premise is based on the fact that the cytokines TNF- $\alpha$ and interleukin- $1 \beta$ (IL-1 $\beta$ ) play an important role in the pathogenesis of many inflammatory diseases, and the signal transduction pathway that results in the production of these cytokines is partially regulated by p38 MAPK (Montalban et al., 2008). The p38 MAPK is activated from an extracellular stimulus, thus phosphorylating and activating other kinases and transcription factors, leading to the stabilization of TNF- $\alpha$ and IL- $1 \beta$ mRNA and to the increase of the gene expression of these cytokines (Palladino et al., 2003).

The relevance of p38 MAPK in inflammatory responses has been shown in a number of studies using chemical inhibitors. Another study using p38 $\alpha$ knockout macrophages demonstrated that deficiency of this protein kinase causes a significant inhibition in the production of TNF- $\alpha$, IL-12, and IL-18 induced by LPS, highlighting the role of p38 $\alpha$ in the activation of these inflammatory cells (Kang et al., 2008).

The description of an initial series of imidazo-pyridine derivatives was an important tool for elucidating the role of $\mathrm{p} 38 \mathrm{MAPK}$ in inflammation. The first pyridinylimidazol described was SKF-86002 (20), with potent activity in modulating the cytokine production stimulated by LPS (Kumar et al., 2003).

In 1993, the structure-activity relationship for antiinflammatory effects of the congener series of pyridinylimidazoles was described by exploring the inhibition of enzymes 5-lipoxygenase/cyclooxygenase (5-LO/COX) and the modulation of cytokine biosynthesis as potential mechanisms of action. Subsequently, the compound SB-203580 (21) and other 2,4,5-triaryl-imidazoles were synthesized and used as pharmacological tools in the search for the molecular target involved in the modulation of cytokine biosynthesis. This study finally allowed the correlation of the desired biological activity with p38 MAPK inhibition, thereby characterizing the potential of this protein kinase as an anti-inflammatory target (Boehm et al., 1996; Kumar et al., 2003). However, further experiments revealed the hepatotoxic and carcinogenic profile of SB-203580 (21) as a result of potent inhibition of cytochrome P450 (Zhang et al., 2007).

Drawing on the description of p38 MAPK as a promising therapeutic target, new inhibitors were designed and obtained using molecular modification strategies, e.g. RWJ-68 354 (22), BIRB-796 (23), SCIO-469 (24), VX702 (25) and VX-745 (26) (Henry et al., 1998; Liverton et al., 1999; Kim et al., 2008). Most of the compounds available act as competitive inhibitors with BIRB-796 (23)<smiles>Fc1ccc(-c2nc3n(c2-c2ccncc2)CCS3)cc1</smiles>

(20) SKF-86002<smiles>CS(=O)c1ccc(-c2nc(-c3ccc(F)cc3)c(-c3ccncc3)[nH]2)cc1</smiles>

(21) SB-203580<smiles>COc1cc(N)nc2[nH]c(-c3ccc(F)cc3)c(-c3ccncc3)c12</smiles>

(22) RWJ-68354<smiles>CC(C)(C)C(=CI)n1nc(C(C)(C)C)cc1NC(=O)Nc1ccc(OCCN2CCOCC2)c2ccccc12</smiles>

(23) BIRB-796<smiles>CC(C)O[Mg]</smiles><smiles>NC(=O)c1ccc(N(C(N)=O)c2c(F)cccc2F)nc1-c1ccc(F)cc1F</smiles>

(25) VX-702<smiles>CC(C)(C)c1ccc(F)c(Cl)c1-c1c(=O)ncn2nc(Sc3ccc(F)cc3F)ccc12</smiles>

constituting one of the few examples of known allosteric inhibitors (Montalban et al., 2008).

The varied safety profiles and different structural classes that encompass the p 38 MAPK inhibitors suggest that the possible toxicity is probably related to the 
structural characteristics of these compounds and not to their mechanism of action. However, despite all research efforts, the employment of a small molecule that acts as an inhibitor of this protein kinase as a drug remains elusive (Montalban et al., 2008).

\section{Modulators of NF- $\mathrm{KB}$ signaling pathway}

The transcription factor NF- $\mathrm{KB}$ plays a central role in inflammation and immune response, acting as a mediator both in TNF- $\alpha$ biosynthesis and in the biological response mediated by the binding of TNF- $\alpha$ to its target receptor (Hanada, Yoshimura, 2002; Lima et al., 2006; Paul et al., 2006). For this reason, the identification of small molecules that inhibit the NF- $\mathrm{\kappa B}$ signaling pathway has emerged as a promising therapeutic approach for the treatment of inflammatory and autoimmune diseases (Hanada, Yoshimura, 2002; Palladino et al., 2003).

In addition to thalidomide (3) and its structural analogues (Figure 2), several classes of compounds have been described as inhibitors of NF- $\kappa \mathrm{B}$ activation, including natural products, e.g. capsaicin (29) and parthenolide (30); non-steroidal anti-inflammatory drugs; glucocorticoids; IKK inhibitors; and proteasome inhibitors (Palladino et al., 2003; De-Blanco et al., 2007).

A broad array of natural products appears to interfere with NF- $\kappa \mathrm{B}$ activation and subsequent gene transcription. Capsaicin (29), for example, reduces the degradation of the inhibitory protein I $\kappa \mathrm{B}-\alpha$ through activation of vanilloid receptors and modification of the redox state of cells. The gene transcriptions dependent on NF- $\kappa \mathrm{B}$ are modulated by antioxidants, e.g. vitamin $\mathrm{E}(\mathbf{3 1})$, and stimulated by reactive oxygen species (Palladino et al., 2003).

Some sesquiterpene lactones found in plants are also able to modulate this signaling pathway. Parthenolide (30), extracted from the medicinal herb Tanacetum parthenium, binds directly and inhibits IKK- $\beta$, i.e. the catalytic subunit of the IKK complex responsible for degradation of IкB- $\alpha$ in response to different pro-inflammatory stimuli (Palladino et al., 2003).

The inhibition of IKK- $\beta$ is a strategy of increasing interest to researchers in academia and in the pharmaceutical industry, resulting in the description of several small
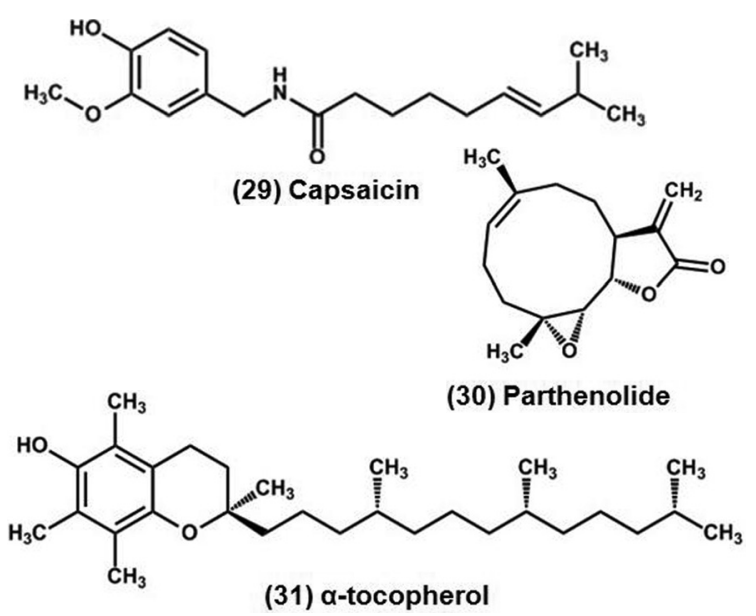

molecules that inhibit IKK- $\beta$, some at the stage of phase I or phase II clinical trials for the treatment of different diseases, predominantly cancer (Edwards et al., 2009). Studies have shown that IKK- $\beta$ deficient cells are defective in activation of NF- $\kappa B$ in response to TNF- $\alpha$ or IL-1 (Li et al., 1999), blocking systemic inflammation in a model of intestinal injury (Knowlton, 2006).

Among the available IKK- $\beta$ inhibitors, some compounds should be highlighted, including TCPA-1 (32, GlaxoSmithKline), ML120B (33, Millennium Pharmaceuticals), SC-514 (34, Pfizer), BMS-345541 (35, Bristol-Myers Squibb) and BAY-117085 (36, Bayer), with proven efficacy and potency in in vitro assays and pronounced anti-inflammatory activity in vivo (Edwards et al., 2009).

TCPA-1 (32), a selective inhibitor of IKK- $\beta$ $\left(\mathrm{IC}_{50}=17.9 \mathrm{nM}\right)$ described by the pharmaceutical industry GlaxoSmithKline, was found to decrease the release of cytokines TNF- $\alpha$, IL- 6 and IL- 8 induced by LPS and significantly reduced the severity of inflammation associated with a murine model of collagen-induced arthritis when therapeutically administered at a dose of $20 \mathrm{mg} / \mathrm{kg}$ (i.p.) (Podolin et al., 2005).

Compounds ML120B (33) and SC-514 (34) are selective, reversible and ATP-competitive IKK- $\beta$ inhibitors, blocking different cellular responses regulated by NF- $\mathrm{\kappa B}$, which are involved in inflammation and the tissue injury

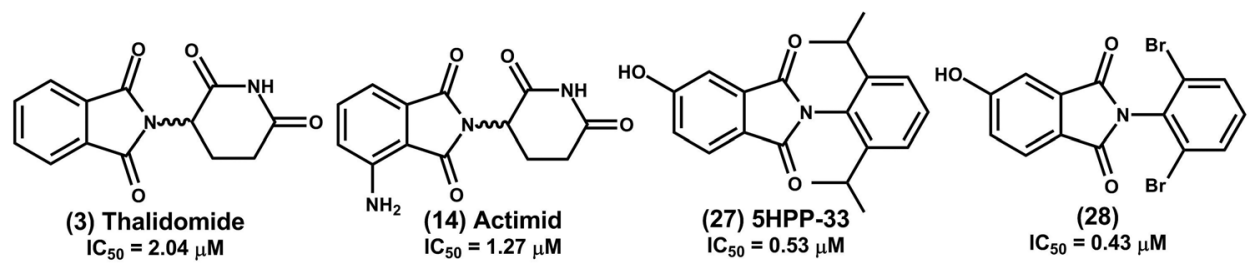

FIGURE 2 - Thalidomide (3) and analogues (14, 27 and 28) and the inhibition of NF- $\kappa$ B translocation to the nucleus in HeLa cell line (human epithelial cells from cervical carcinoma) (De-Blanco et al., 2007). 


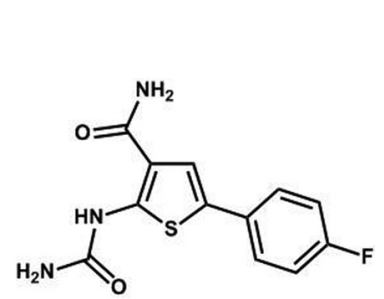

(32) TCPA-1

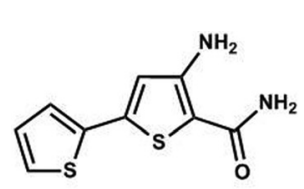

(34) SC-514

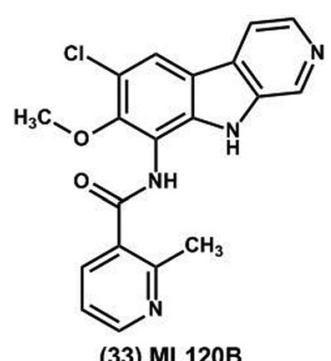

(33) ML120B<smiles>Cc1ccc2nc(NCCN)c3ncc(C)n3c2c1</smiles>

(35) BMS-345541<smiles>CC(C)(C)c1ccc(S(=O)(=O)/C=C/C#N)cc1</smiles>

process characteristic of rheumatoid arthritis (Kishore et al., 2003; Wen et al., 2006).

Prototype BMS-345541 (35) (Bristol-Myers Squibb) on the other hand, is an allosteric inhibitor of both catalytic subunits of IKK complex, with $\mathrm{IC}_{50}$ equal to $0.3 \mu \mathrm{M}$ for IKK- $\beta$ and $4 \mu \mathrm{M}$ for IKK- $\alpha$. This compound inhibits the release of cytokines TNF- $\alpha$, IL- $1 \beta$, IL- 6 and IL-8 in vitro, and presents a suitable pharmacokinetic profile in mice, being able to modulate the in vivo production of TNF- $\alpha$ induced by LPS after oral administration (Burke et al., 2003).

BAY-117085 (36), identified by researchers at Bayer, inhibits the phosphorylation of inhibitory protein I $\kappa \mathrm{B}-\alpha$ in a selective and irreversible manner, producing an in vivo anti-inflammatory effect in murine models of carrageenan-induced paw edema and arthritis induced by adjuvant (Pierce et al., 1997).

Additionally, proteasome inhibitors, which affect signaling via NF- $\mathrm{\kappa B}$, have also been identified as promising disease modifying anti-inflammatory agents (Edwards et al., 2009).

The ubiquitin-proteasome system (UPS) is responsible for the proteolytic degradation of most cellular proteins, such as the inhibitory protein I $\kappa$ B- $\alpha$, thus playing a relevant role in the modulation of NF- $\kappa \mathrm{B}$ activity. The $26 \mathrm{~S}$ proteasome consists of an ATP-dependent proteolytic complex, constituted by a proteolytic core called $20 \mathrm{~S}$ proteasome, associated with two 19S regulatory subunits (Adams, 2003; Voorhees, Orlowski, 2006).

Compounds described as proteasome inhibitors present anti-tumor activity in vitro and in vivo, and bort- ezomib (37, Millennium Pharmaceuticals) was the first to be evaluated in clinical trials, demonstrating efficacy in the treatment of multiple myeloma and non-Hodgkin lymphoma (Voorhees, Orlowski, 2006).

Some natural products have also been identified as inhibitors of this proteolytic complex, e.g. lactacystin (38) and epoxomicin (39), which irreversibly inhibit the $20 \mathrm{~S}$ proteasome (Voorhees, Orlowski, 2006).
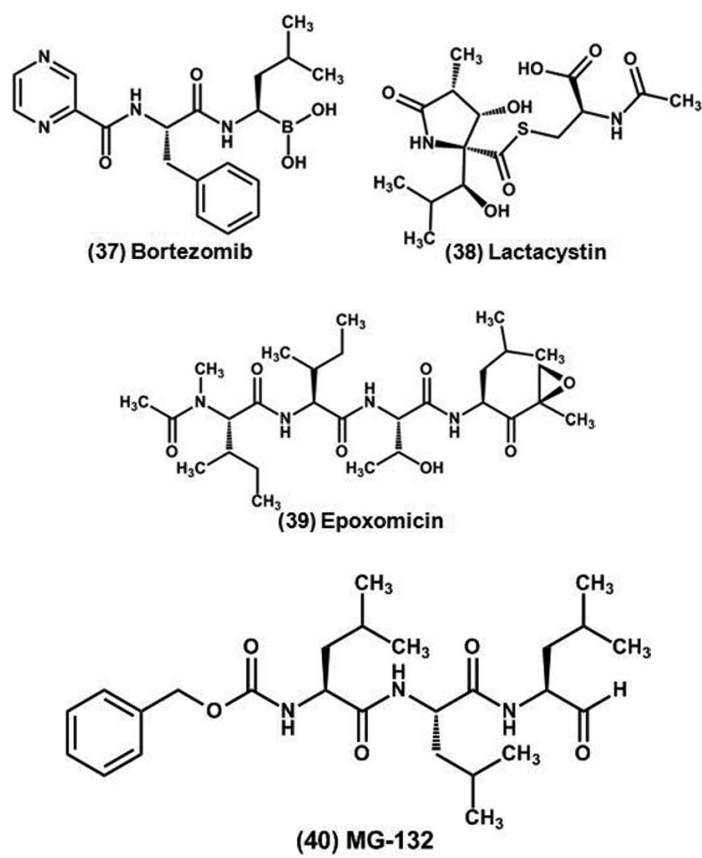

Conversely, the synthetic tripeptide aldehyde MG132 (40) binds and inhibits the active site of the 20S proteasome through the formation of a reversible hemiacetal, resulting in promising anti-inflammatory effects in asthma and chronic obstructive pulmonary disease (COPD). Studies have demonstrated the ability of $\mathbf{4 0}$ to reduce the inflammation associated with allergic stimulus, the function of eosinophils, and, therefore, the release of mediators responsible for tissue injury by these cells (Voorhees, Orlowski, 2006; Edwards et al., 2009).

\section{Modulators of intracellular CAMP levels}

3',5'-cyclic adenosine monophosphate (cAMP) and 3',5'-cyclic guanosine monophosphate (cGMP) are second messengers generated by the action of adenylate cyclase and guanylate cyclase, respectively, which are involved in a vast array of cellular responses to different stimuli (Figure 3) (Lima et al., 2002; Chung, 2006).

These second messengers activate specific intracellular proteins, such as protein kinase A and protein kinase $\mathrm{G}$, which phosphorylate proteins that regulate different physiological processes, e.g. transcription factors and ion 


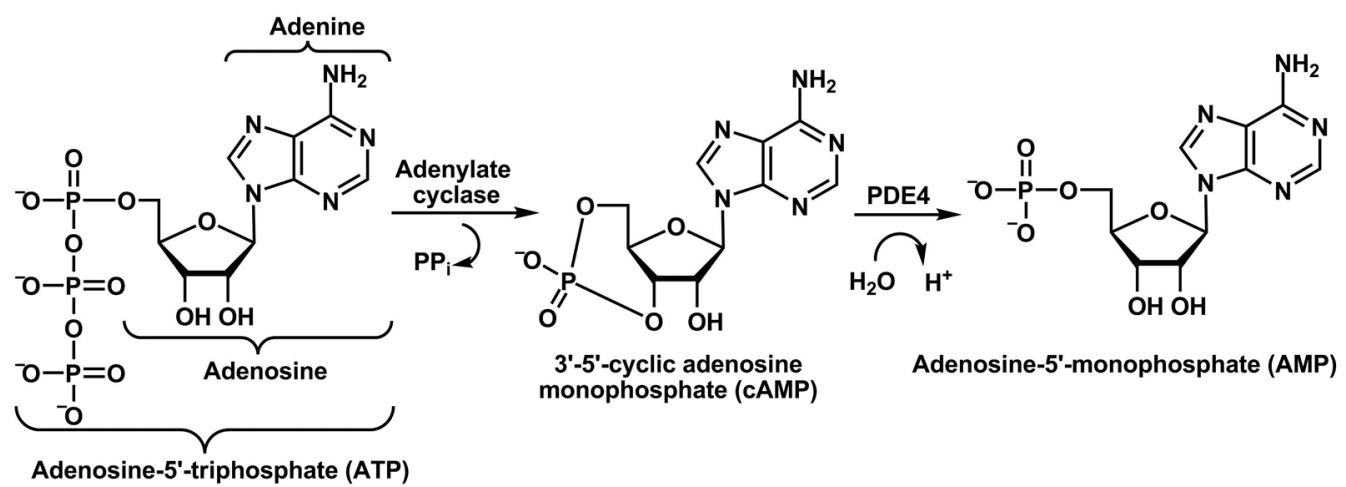

FIGURE 3 - Biosynthesis of cAMP by adenylate cyclase and its hydrolysis to adenosine-5'-monophosphate (AMP) by the action of phosphodiesterase 4 (PDE4).

channels, resulting in diverse biological effects. In the inflammatory response, the activation of protein kinase A prevents transcriptional factors, such as NF- $\kappa \mathrm{B}$, from promoting the expression of genes encoding cytokines. Thus, agents that induce higher levels of cAMP, either by stimulating its formation or by preventing its degradation, inhibit pro-inflammatory cytokines, e.g. TNF- $\alpha$ and IL-1 $\beta$, resulting in an immunosuppressive effect (Figure 4) (Chung, 2006).

In this context, new classes of drugs able to modulate intracellular levels of cAMP emerge as useful therapeutic strategies, such as phosphodiesterase inhibitors and modulators of the adenosine system (Lipworth, 2005; Chung, 2006; Jacobson, Gao, 2006).

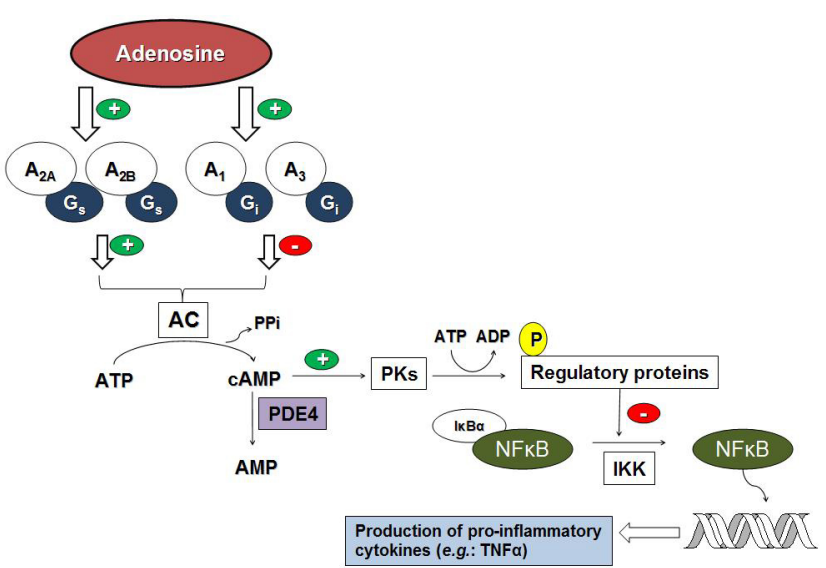

FIGURE 4 - Biology of cAMP and its role in the modulation of inflammatory response.

\section{- Phosphodiesterase inhibitors}

Phosphodiesterases are a group of eleven families of enzymes (PDEs 1-11) responsible for the hydrolysis of cyclic nucleotides cAMP and cGMP, generating the respective 5'-monophosphates. These families of phosphodiestera- ses are expressed differently in different tissues and diverge in terms of amino acid sequence, substrate specificity, sensitivity to certain inhibitors, biochemical parameters and modulation of enzyme activity. For the last decade, studies involving the control of cAMP and cGMP levels through the activity of PDEs have intensified, with their relevance evidenced by the number of clinical trials of selective PDE inhibitors for various inflammatory diseases, e.g. asthma and COPD (Lipworth, 2005; Chung, 2006).

Phosphodiesterase 4 (PDE4) in particular plays a central role in the immune cells involved in inflammatory response and is predominantly expressed in mast cells, eosinophils, neutrophils, T lymphocytes, macrophages and some structural cells, e.g. epithelial cells and neurons. The PDE4 family, specific for cAMP hydrolysis, is divided into four subtypes, PDE4A, PDE4B, PDE4C and PDE4D (Houslay et al., 2005; Chung, 2006).

Rolipram (41), developed by Schering AG pharmaceutical industry, is a highly selective first generation PDE4 inhibitor used as a pharmacological tool for investigating the role of this enzyme. This compound has antiinflammatory and immunomodulatory effects, and inhibits the release of cytokines from activated $\mathrm{T}$ lymphocytes, basophils, monocytes, macrophages and airway epithelial cells (Chung, 2006).

In a bid to reduce the adverse effects associated with this class of drugs, the occurrence of nausea and vomiting in particular, several second generation PDE4 inhibitors were described, such as Cilomilast (42, GlaxoSmithKline) and Roflumilast (43, Altana), which reached the stage of phase III clinical trials (Houslay et al., 2005; Lipworth, 2005).

Recent studies describe the involvement of PDE4 subtypes in the onset of the different biological effects of these inhibitors. The PDE4B appears to mediate most of the anti-inflammatory effects, while PDE4D is responsible for the adverse effects reported, mainly emesis (Lipworth, 
<smiles>COc1ccc(C2CNC(=O)C2)cc1OC1CCCC1</smiles><smiles>CCCCCCC(C#N)(CCCC(CC)C(=O)O)c1ccc(OC)c(OC2CCCC2)c1</smiles><smiles>O=C(Nc1c(Cl)cncc1Cl)c1ccc(OC(F)F)c(OCC2CC2)c1</smiles>

(43) Roflumilast

2005). Researchers have described that PDE4D knockout mice showed no adverse effects, while studies with PDE4B knockout mice confirmed that this PDE4 subtype is essential for biosynthesis of TNF- $\alpha$ induced by LPS in vivo (Boswell-Smith et al., 2006). PDE4B knockout animals have shown almost complete suppression of this cytokine (Yamamoto et al., 2007), suggesting that a PDE4B selective inhibitor could potentially be an effective anti-inflammatory agent which does not induce emesis (Boswell-Smith et al., 2006).

Cilomilast (42) is ten times more selective for PDE4D than for other isoenzymes (i.e., PDE4A, PDE4B and PDE4C), while Roflumilast (43) shows no selectivity for the different isoforms of PDE4. The selectivity of $\mathbf{4 2}$ for PDE4D, responsible for the induction of nausea in patients, explains why this compound is less tolerated than Roflumilast (43) (Lipworth, 2005).

The search for PDE4 inhibitors without emetic effects led to the discovery of compounds with lower activity against the PDE4D isoform, such as the indole derivative AWD-12-281 (44, GlaxoSmithKline), the indazole derivative Tofimilast (45, Pfizer), and the benzofuran derivative Lirimilast (46, Bayer) (Houslay et al., 2005).

- Modulators of the adenosine system

Adenosine is an endogenous purine nucleoside (Figure 4) released by various cells, which regulates physiological processes by activating specific receptors. There are four known subtypes of adenosine receptors, named $A_{1}$, $A_{2 A}, A_{2 B}$ and $A_{3}$, all coupled to the $G$ protein, related to a variety of signal transduction pathways (Haskó, Cronstein, 2004; Zhang et al., 2005).

The release of adenosine is increased in response to tissue injury. An accentuated production of this nucleoside is described in several pathological conditions, e.g. inflammation, hypoxia and ischemia. Adenosine can be metabolized by action of the enzyme adenosine deami-
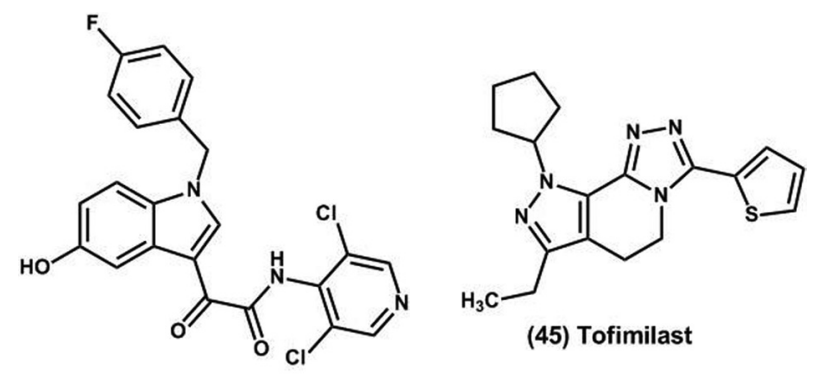

(45) Tofimilast

(44) AWD-12-281

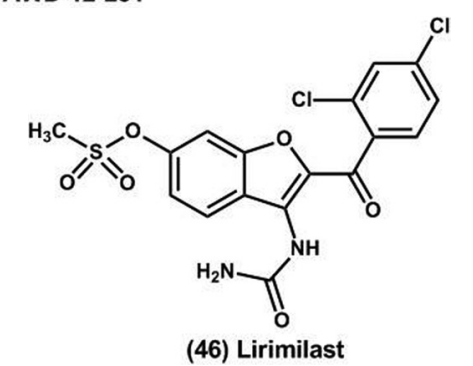

nase, leading to inosine; or can be converted intracellularly to the nucleotide adenosine monophosphate (AMP) by the action of the enzyme adenosine kinase (Fredholm et al., 2001; Zhang et al., 2005).

Each adenosine receptor subtype has its particularities with regard to signaling and final physiological effects. In the classical description, the signaling triggered by these receptors is mediated by inhibition or stimulation of adenylate cyclase, although there are current indications of the relevance of other mediators and enzymes, e.g. calcium, phospholipase $\mathrm{C}$ and mitogen-activated protein kinases (MAPKs) (Jacobson, Gao, 2006).

The $\mathrm{A}_{2 \mathrm{~A}}$ and $\mathrm{A}_{2 \mathrm{~B}}$ receptors, coupled to stimulatory $G$ protein, activate adenylate cyclase and increase intracellular cAMP (Figure 4). On the other hand, the $\mathrm{A}_{1}$ and $A_{3}$ receptors coupled to inhibitory $G$ protein, reduce the release of intracellular cAMP. Thus, several studies have shown that agonists of $\mathrm{A}_{2 \mathrm{~A}}$ and $\mathrm{A}_{2 \mathrm{~B}}$ receptors could act as anti-inflammatory agents, and this activity was attributed, at least in part, to reduced release of TNF- $\alpha$. However, recent studies have indicated that activation of $\mathrm{A}_{2 \mathrm{~B}}$ receptors is also associated with the release of several allergic and pro-inflammatory mediators, whereas activation of the $\mathrm{A}_{2 \mathrm{~A}}$ receptor present in most immune cells including lymphocytes, monocytes, macrophages and dendritic cells, appears to effectively alleviate inflammation and reperfusion injury in different tissues (Zhang et al., 2005; Jacobson, Gao, 2006).

In this context, several $\mathrm{A}_{2 \mathrm{~A}}$ receptor agonists have been reported in the literature as drug candidates for the treatment of inflammatory diseases. For example, the $\mathrm{A}_{2 \mathrm{~A}}$ receptor agonist BMS-068645 (ATL-146e) (47), developed by Bristol-Myers Squibb, has a promising anti- 
inflammatory profile associated with the modulation of TNF- $\alpha$ and interferon gamma (INF- $\gamma$ ) release by activated $\mathrm{T}$ lymphocytes, limiting the activation of T cells and macrophages in inflamed tissues. Conversely, the prototype CGS21680 (48), produced by Novartis, has pronounced anti-inflammatory activity in different murine models of allergic asthma, emerging as an alternative therapy for the treatment of this disease (Jacobson, Gao, 2006).

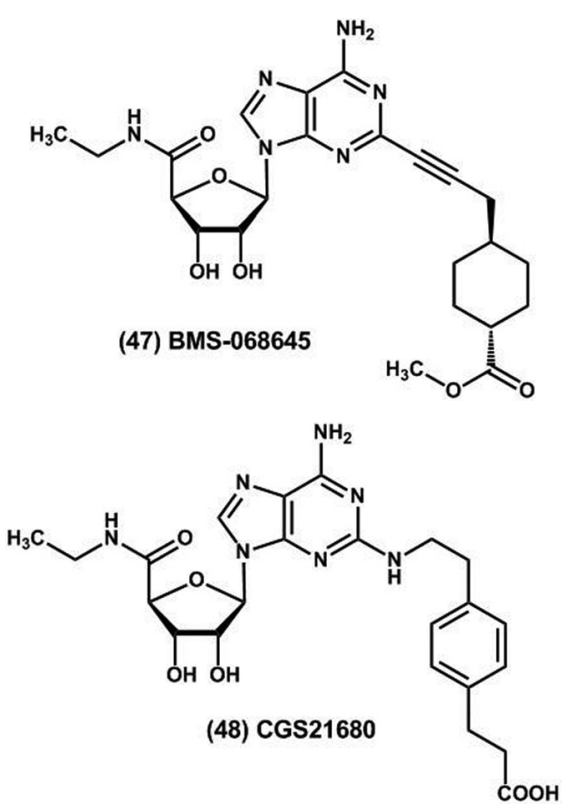

\section{Dual inhibitors of TNF- $\alpha$ and PDE4}

Aiming to optimize TNF- $\alpha$ modulator activity, different research groups have explored the ability of thalidomide (3) and derivatives to directly inhibit the biosynthesis of this cytokine associated with the strategy of indirect modulation, which is based on increasing the intracellular cAMP concentration (Lima et al., 2006). Agents that induce higher levels of cAMP, either by stimulating its production or preventing its degradation, cause an inhibition of pro-inflammatory cytokines such as TNF- $\alpha$, IL-1 $\beta$ and INF- $\gamma$, reducing the recruitment and activation of inflammatory cells resulting in an immunosuppressive effect (Marriott et al., 1997; Gallant et al., 2008).

Muller and colleagues described phthalimidic analogues of thalidomide (3) containing the dialcoxy-phenyl core, a pharmacophoric group present in PDE4 inhibitors, e.g. rolipram (41), cilomilast (42) and roflumilast (43), aiming to obtain dual inhibitors of TNF- $\alpha$ and PDE4. The new phthalimidic dialcoxy-phenyl derivatives (49-52, Figure 5) effectively reduced TNF- $\alpha$ release in peripheral blood mononuclear cells stimulated by LPS, and significantly inhibited the enzymatic activity of PDE4, acting through a different mechanism of action to that described for prototype 3 (Muller et al., 1998; Lima et al., 2006).

The Laboratório de Avaliação e Síntese de Substâncias Bioativas (LASSBio ${ }^{\circledR}$ ), of the Federal University of Rio de Janeiro, has also made its contribution to the research and development of dual inhibitors of TNF- $\alpha$ and PDE4. In this lab, a congener series of $N$-phenyl sulfonamide phthalimidic derivatives designed by molecular hybridization of the prototype thalidomide (3) with the selective PDE-4 inhibitor $N$-(2,3-dihydro-1H-1-indenil)3,4-dimethoxy-benzene-sulfonamide (53) was synthesized (Figure 6) (Montana et al., 1998; Lima et al., 2002; Lima et al., 2006).

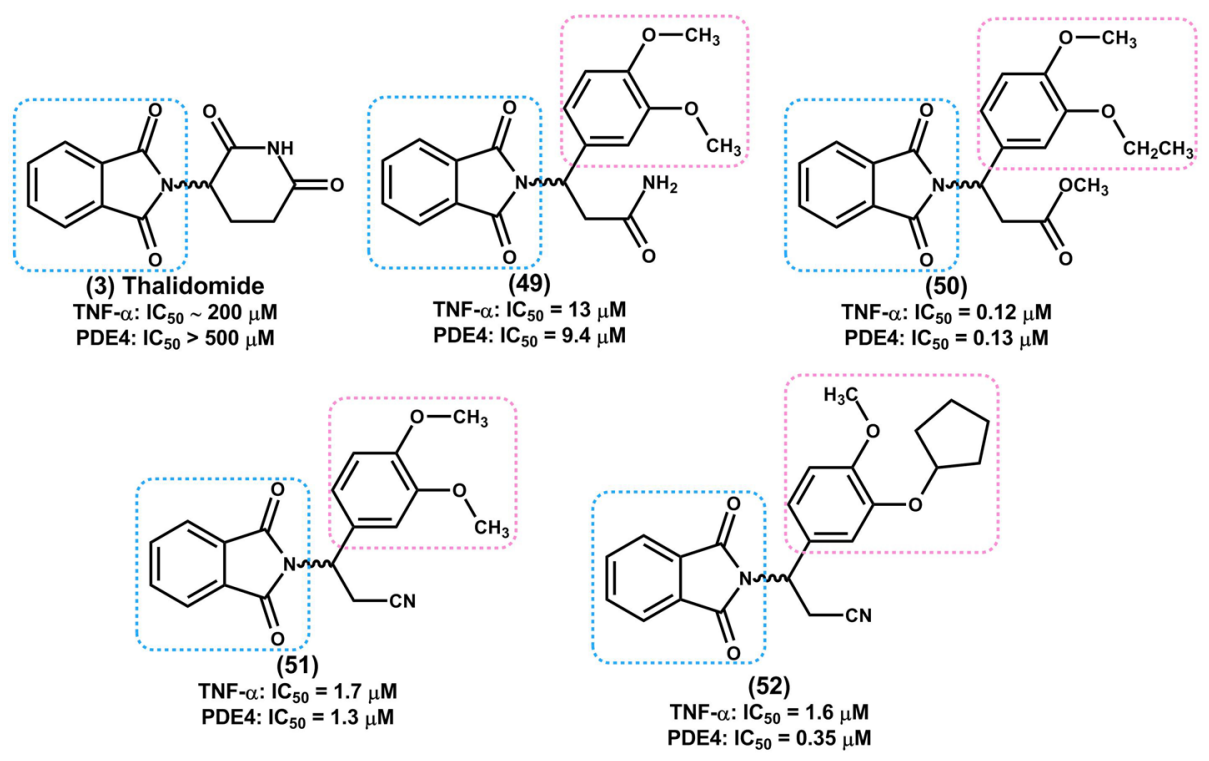

FIGURE 5 - Inhibitory activity of thalidomide (3) and analogues (49-52) in the TNF- $\alpha$ release in peripheral blood mononuclear cells stimulated by LPS and in the enzymatic activity of PDE4 (Muller et al., 1998). 
The determination of the anti-inflammatory properties of the new $N$-phenyl sulfonamide phthalimidic derivatives (54-58) was carried out according to the pharmacological protocol for acute lung inflammation induced by LPS inhalation in mice. The results indicated good overall anti-inflammatory activity for this new series of derivatives when administered intraperitoneally, especially the compound LASSBio-468 (58), which showed an $\mathrm{ED}_{50}$ of $2.5 \mathrm{mg} / \mathrm{kg}$ in this assay (Lima et al., 2002).

The identified prototype (58) also reduced TNF- $\alpha$ mRNA levels analyzed by reverse transcription polymerase chain reaction (RT-PCR) in mice peritoneal macrophages stimulated by LPS (Alexandre-Moreira et al., 2005); and significantly inhibited the NF- $\kappa \mathrm{B}$ activation induced by TNF- $\alpha$ at concentrations greater than $257 \mu \mathrm{M}(100 \mathrm{mg} /$ $\mathrm{mL}$ ) in U937 cell line, comprising monocytic cells extracted from human histiocytic lymphoma (Abreu, 2007).

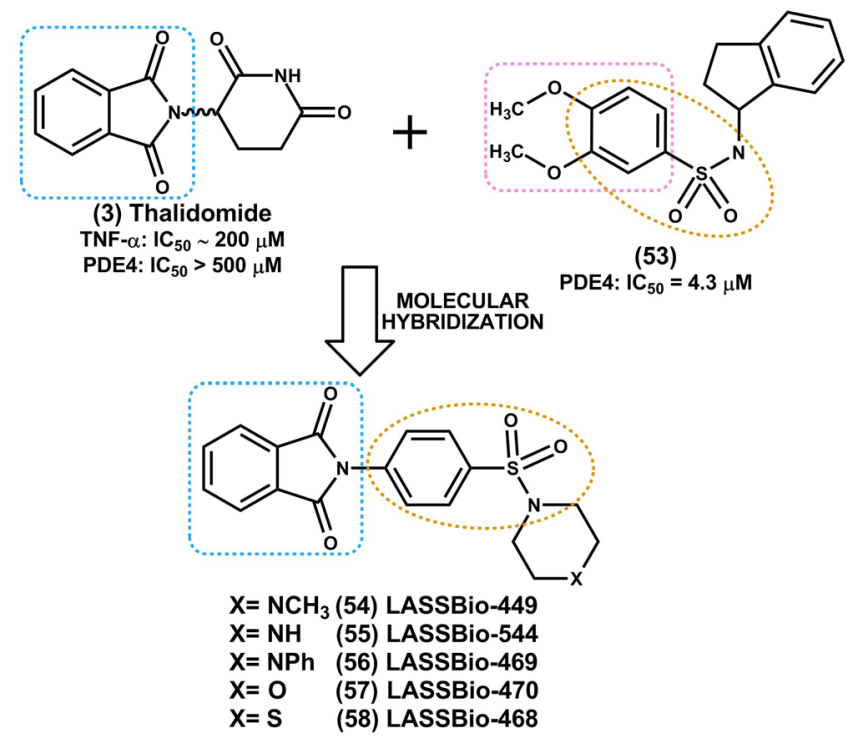

FIGURE 6 - Structural design of the $N$-phenyl sulfonamide phthalimidic derivatives, idealized as dual inhibitors of TNF- $\alpha$ and PDE4 (Lima et al., 2002).

In addition to the anti-TNF- $\alpha$ activity previously described, LASSBio-468 (58) showed the ability to inhibit PDE-4 isoform in vitro $\left(\mathrm{IC}_{50}=80 \mu \mathrm{M}\right)$ and was also found to be inactive against the other isoforms of this enzyme (PDE1, PDE2, PDE3 and PDE5) at concentrations greater than $300 \mu \mathrm{M}$ (Alexandre-Moreira et al., 2005).

This prototype has a pronounced anti-inflammatory and immunomodulatory profile, possibly resulting from a complex mechanism of action involving, besides the elevation of cAMP levels in immunocompetent cells, other independent biological properties, including the ability to reduce the stability of TNF- $\alpha$ mRNA (Alexandre-Moreira et al., 2005; Lima et al., 2006).

\section{FINAL CONSIDERATIONS}

The anti-TNF biological therapies currently available in the pharmaceutical market have led to a revolution in the treatment of chronic degenerative inflammatory diseases, characterizing this therapeutic approach as effective in improving the quality of life of a significant number of patients. Worldwide, approximately one million individuals are either undergoing treatment or have been treated with TNF inhibitors, comprising indications that include rheumatoid arthritis, psoriatic arthritis, psoriasis and inflammatory bowel diseases. In addition, numerous potential clinical applications are still undergoing evaluation. However, these therapies have risks and limitations associated with their continued employment including their high cost, the inconvenience of exclusive administration in hospitals and the incidence of significant adverse effects such as a high susceptibility to infections.

In this context, the discovery of small molecules able to modulate TNF activities, preferentially when administered orally, could represent an alternative to biopharmaceutical agents. To this end, different mechanisms of TNF modulation have been characterized, e.g. the inhibition of TACE; the inhibition of protein kinases, such as p38 MAPK; the modulation of NF- $\mathrm{KB}$ signaling pathway; and the increase in intracellular cAMP levels through the use of phosphodiesterase inhibitors and/or adenosine system modulators; offering a wide range of possible targets for the design and development of new drug candidates with better pharmacotherapeutic profiles.

\section{REFERENCES}

ABREU, T. P. Estudo de derivados ftalimídicos análogos à talidomida: inibição do fator transcricional NF- $\mathrm{KB} \mathrm{e}$ investigação da ação anti-angiogênica. Rio de Janeiro, 2007. 121 p. [Master's Degree Thesis in Genetics. Institute of Biology. Federal University of Rio de Janeiro].

ADAMS, J. Potential for proteasome inhibition in the treatment of cancer. Drug Discov. Today, v.8, n.7, p.307-315, 2003.

ALEXANDRE-MOREIRA, M.S.; TAKIYA, C.M.; ARRUDA, L.B., PASCARELLI, B.; GOMES, R.N.; FARIA NETO, H.C.; LIMA, L. M..; BARREIRO, E. J. LASSBio-468: a new achiral thalidomide analogue with modulates TNF- $\alpha$ and NO production and inhibits endotoxic shock and arthritis in na animal model. Int. Immunopharmacol., v.5, n.3, p.485-494, 2005. 
ARANAPAKAM, V.; DAVIS, J.M.; GROSU, G.T.; BAKER, J.; ELLINGBOE, J.; ZASK, A.; LEVIN, J.I.; SANDANAYAKA, V.P.; DU, M.; SKOTNICKI, J.S.; DIJOSEPH, J.F.; SUNG, A.; SHARR, M.A.; KILLAR, L.M.; WALTER, T.; JIN, G.; COWLING, R.; TILLETT, J.; ZHAO, W.; MCDEVITT, J.; XU, Z.B. Synthesis and structure-activity relationship of $N$-substituted 4-arylsulfonylpiperidine-4-hydroxamic acids as novel, orally active matrix metalloproteinase inhibitors for the treatment of osteoarthritis. J. Med. Chem., v.46, n.12, p.2376-2396, 2003.

BANNER, D. W.; D'ARCY, A.; JANES, W.; GENTZ, R.; SCHOENFELD, H-J.; BROGER, C.; LOETSCHER, H.; LESSLAUER, W. Crystal structure of the soluble human 55kDa TNF receptor-human TNF $\beta$ complex: implications for TNF receptor activation. Cell, v.73, n.3, p.431-445, 1993.

BECK, G.; BOTTOMLEY, G.; BRADSHAW, D.; BREWSTER, M.; BROADHURST, M.; DEVOS, R.; HILL, C.; JOHNSON, W.; KIM, H.J.; KIRTLAND, S.; KNEER, J.; LAD, N.; MACKENZIE, R.; MARTIN, J.; NIXON, J.; PRICE, G.; RODWELL, A.; ROSE, F.; TANG, J.P.; WALTER, D.S.; WILSON, K.; WORTH, E. $(E)-2(R)-[1(S)-$ (hydroxycarbamoyl)-4-phenyl-3-butenyl]-2'-isobutyl-2'(methanesulfonyl)-4-methylvalerohydrazide (Ro 32-7315), a selective and orally active inhibitor of tumor necrosis factor- $\alpha$ convertase. J. Pharmacol. Exp. Ther, v.302, n.1, p.390-396, 2002.

BLACK, R. A.; BIRD, T. A., MOHLER, K. M. Agents that block TNF- $\alpha$ synthesis or activity. Annu. Rep. Med. Chem., v.32, p.241-249, 1997.

BOEHM, J. C.; SMIETANA, J. M.; SORENSON, M. E.; GARIGIPATI, R. S.; GALLAGHER, T. F.; SHELDRAKE, P. L.; BRADBEER, J.; BADGER, A. M.; LAYDON, J. T.; LEE, J. C.; HILLEGASS, L. M.; GRISWOLD, D. E.; BRETON, J. J.; CHABOT-FLETCHER, M. C.; ADAMS, J. L. 1-Substituted 4-Aryl-5-pyridinylimidazoles: a new class of cytokine suppressive drugs with low 5-lipoxygenase and cyclooxygenase inhibitory potency. J. Med. Chem., v.39, n.20, p.3929-3937, 1996.

BOSWELL-SMITH, V.; SPINA, D.; PAGE, C.P. Phosphodiesterase inhibitors. Br. J. Pharmacol., v.147, n.S1, p.S252-S257, 2006.
BRAKEBUSCH, C.; VARFOLOMEEV, E.E.; BATKIN,M.; WALLACH, D. Structural requirements for inducible shedding of the p55 tumor necrosis factor receptor. J. Biol. Chem., v.269, n.51, p.32488-32496, 1994.

BURKE, J.R.; PATTOLI, M.A.; GREGOR, K.R.; BRASSIL, P.J.; MACMASTER, J.F.; MCINTYRE, K.W.; YANG, X.; IOTZOVA, V.S.; CLARKE, W.; STRNAD, J.; QIU, Y.; ZUSI, C. BMS-345541 is a highly selective inhibitor of I $\mathrm{B}$ kinase that binds at an allosteric site of the enzyme and blocks NFKB-dependent transcription in mice. J. Biol. Chem., v.278, n.3, p.1450-1456, 2003.

CAPORALI; R.; PALLAVICINI, F.B.; FILIPPINI, M.; GORLA, R.; MARCHESONI, A.; FAVALLI, E.G.; SARZIPUTTINI, P.; ATZENI, F.; MONTECUCCO, C. Treatment of rheumatoid arthritis with anti-TNF-alpha agents: A reappraisal. Autoimmun. Rev., v.8, n.3, p.274-280, 2009.

CAWTHORN, W.P.; SETHI, J.K. TNF- $\alpha$ and adipocyte biology. FEBS Letters, v.582, n.1, p.117-131, 2008.

CHERNEY, R.J.; KING, B.W.; GILMORE, J.L.; LIU, R.Q.; COVINGTON, M.B.; DUAN, J.J.W.; DECICCO, C.P. Conversion of potent MMP inhibitors into selective TACE inhibitors. Bioorg. Med. Chem. Lett., v.16, n.4, p.10281031, 2006.

CHUNG, K.F. Phosphodiesterase inhibitors in airways disease. Eur. J. Pharmacol., v.533, n.1-3, p.110-117, 2006.

CORRAL, L.G.; KAPLAN, G. Immunomodulation by thalidomide and thalidomide analogues. Ann. Rheum. Dis., v.58, suppl.1, p.1107-1113, 1999.

DASGUPTA, S.; MURUMKAR, P.R.; GIRIDHAR, R.; YADAV, M.R. Current perspective of TACE inhibitors: A review. Bioorg. Med. Chem., v.17, n.2, p.444-459, 2009.

DENG, L.; DING, W.; GRANSTEIN, R.D. Thalidomide inhibits tumor necrosis factor- $\alpha$ production and antigen presentation by Langerhans cells. J. Invest. Dermatol., v.121, n.5, p.1060-1065, 2003.

DE-BLANCO, E.J.C.; PANDIT, B.; HU, Z.; SHI, J.; LEWIS, A.; LI, P.K. Inhibitors of NF- $\kappa \mathrm{B}$ derived from thalidomide. Bioorg. Med. Chem. Lett., v.17, n.21, p.6031-6035, 2007. 
DUAN, J.J.W.; CHEN, L.; WASSERMAN, Z.R.; LU, Z.; LIU, R.Q.; COVINGTON, M.B.; QIAN, M.; HARDMAN, K.D.; MAGOLDA, R.L.; NEWTON, R.C.; CHRIST, D.D.; WEXLER, R.R.; DECICCO, C.P. Discovery of $\gamma$-lactam hydroxamic acids as selective inhibitors of tumor necrosis factor- $\alpha$ converting enzyme: design, synthesis, and structure-activity relationships. J. Med. Chem., v.45, n.23, p.4954-4957, 2002.

EDWARDS, M.R.; BARTLETT, N.W.; CLARKE, D.; BIRRELL, M.; BELVISI, M.; JOHNSTON, S.L. Targeting the NF$\kappa \mathrm{B}$ pathway in asthma and chronic obstructive pulmonary disease. Pharmacol. Ther., v.121, n.1, p.1-13, 2009.

FELDMANN, M.; BRENNAN, F.M.; FOXWELL, B.M.J.; TAYLOR, P.C.; WILLIAMS, R.O; MAINI, R.N. Anti-TNF therapy: where have we got to in 2005? J. Autoimmun., v.25, suppl.1, p.26-28, 2005.

FREDHOLM, B.B.; IJZERMAN, A.P.; JACOBSON, K.A.; KLOTZ, K.N.; LINDEN, J. International union of pharmacology. XXV. Nomenclature and classification of adenosine receptors. Pharmacol. Rev., v.53, n.4, p.527$552,2001$.

GALlANT, M.; CHAURET, N.; CLAVEAU, D.; DAY, S.; DESCHÊNES, D.; DUBÉ, D.; HUANG, Z.; LACOMBE, P.; LALIBERTÉ, F.; LÉVESQUE, J-F; LIU, S.; MACDONALD, D.; MANCINI, J.; MASSON, P.; MASTRACCHIO, A.; NICHOLSON, D.; NICOLLGRIFFITH, D.A.; PERRIER, H.; SALEM, M.; STYHLER, A.; YOUNG, R.N.; GIRARD, Y. Design, synthesis and biological evaluation of 8-biarylquinolines: a novel class of PDE4 inhibitors. Bioorg. Med. Chem. Lett., v.18, n.4, p.1407-1412, 2008.

GEARING, A. J. H.; BECKETT, P.; CRISTODOULOU, M.; DRUMMOND, A. H.; GALLOWAY, W. A.;GILBERT, R.; GORDON, J. L.; LEBER, T. M.; MAGAN, M.; MILLER, K.; NAYEE, P.; OWEN, K.; PATEL, S.; THOMAS, G.; WELLS, G.; WOOD, L. M.; WOOLLEY, K. Processing of tumor necrosis factor- $\alpha$ precursor by metalloproteinases. Nature, v.370, n.6490, p.555-557, 1994.

GRAY, P. W.; AGGARWAL, B. B.; BENTON, C. V.; BRINGMAN, T. S.; HENZEL, W. J.; JARRETT, J. A.; LEUNG, D. W.; MOFFAT, B.; NG, P.; SVEDERSKY, L. P.; PALLADINO, M. A.; NEDWIN, G. E. Cloning and expression of cDNA for human lymphotoxin, a lymphokine with tumor necrosis activity. Nature, v.312, n.5996, p.721$724,1984$.
HANADA, T.; YOSHIMURA, A. Regulation of cytokine signaling and inflammation. Cytokine Growth Factor Rev., v.13, n.4, p.413-421, 2002.

HASHIMOTO, Y. Structural development of biological response modifiers based on thalidomide. Bioorg. Med. Chem., v.10, n.3, p.461-479, 2002.

HASKÓ, G.; CRONSTEIN, B.C. Adenosine: an endogenous regulator of innate immunity. Trends Immunol., v.25, n.1, p.33-39, 2004.

HENRY, J. R.; RUPERT, K. C.; DODD, J. H.; TURCHI, I. J.; WADSWORTH, S. A.; CAVENDER, D. E.; FAHMY, B.; OLINI, G. C.; DAVIS, J. E.; PELLEGRINO-GENSEY, J.; SCHAFER, P. H.; SIEKIERKA,J. J. 6-Amino-2-(4fluorophenyl)-4-methoxy-3-(4-pyridyl)-1 $H$-pyrrolo[2,3- $b]$ pyridine (RWJ 68354): A potent and selective p38 kinase inhibitor. J. Med. Chem., v.41, n.22, p.4196-4198, 1998.

HOCHBERG, M.C.; LEBWOHL, M.G.; PLEVY, S.E.; HOBBS, K.F.; YOCUM, D.E. The benefit/risk profile of TNF-blocking agents: findings of a consensus panel. Sem. Arthritis Rheum., v.34, n.6, p.819-836, 2005.

HORSSEN, R.V.; HAGEN, T.L.M.; EGGERMONT, A.M.M. TNF- $\alpha$ in cancer treatment: molecular insights, antitumor effects, and clinical utility. Oncologist, v.11, p.397-408, 2006.

HOUSLAY, M.D.; SCHAFER, P.; ZHANG, K.Y.J. Keynote review: Phosphodiesterase-4 as a therapeutic target. Drug Discov. Today, v.10, n.22, p.1503-1519, 2005.

JACOBSON, K.A.; GAO, Z.G. Adenosine receptor as therapeutic targets. Nat. Rev. Drug Discov., v.5, n.3, p.247264, 2006.

KANG, Y.J.; CHEN, J.; OTSUKA, M.; MOLS, J.; REN, S.; WANG, Y.; HAN, J. Macrophage deletion of p38 $\alpha$ partially impairs lipopolysaccharide-induced cellular activation. $J$. Immunol., v.180, n.7, p.5075-5082, 2008.

KARIN, M . The IKKbeta subunit of IkappaB kinase (IKK) is essential for nuclear factor kappa B activation and prevention of apoptosis. J. Exp. Med., v.189, n.11, p.1839$1845,1999$.

KENNY, P.A. TACE: a new target in epidermal growth factor receptor depedent tumors. Differentiation, v.75, n.9, p.800$808,2007$. 
KEIFER, J.; GUTTRIDGE, D.; ASHBURNER, B.; BALDWIN, A. Inhibition of $\mathrm{NF} \kappa \mathrm{B}$ activity by Thalidomide through suppression of IкB Kinase activity. J. Biol. Chem., v.276, n.25, p.22382-22387, 2001.

KIM, Y.S.; KIM, J.S.; JUNG, H.C.; SONG, I.S. The effects of thalidomide on the stimulation of NF-карраB activity and TNF-alpha production by lipopolysaccharide in human colonic epithelial cell line. Mol. Cell, v.17, n.2, p.210-216, 2004.

KIM, D.K.; LIM, J.H.; LEE, J.A.; DEWANG, P.M. Synthesis and biological evaluation of trisubstituted imidazole derivatives as inhibitors of $\mathrm{p} 38 \alpha$ mitogen-activated protein kinase. Bioorg. Med. Chem. Lett., v.18, n.14, p.4006-4010, 2008.

KISHORE, N.; SOMMERS, C.; MATHIALAGAN, S.; GUZOVA, J.; YAO, M.; HAUSER, S.; HUYNH, K.; BONAR, S.; MIELKE, C.; ALBEE, L.; WEIER, R.; GRANETO, M.; HANAU, C.; PERRY, T.; TRIPP, C.S. A selective IKK-2 inhibitor blocks NF $\kappa B$-dependent gene expression in interleukin-1 $\beta$-stimulated synovial fibroblasts. J. Biol. Chem., v.278, n.35, p.32861-32871, 2003.

KNOWLTON, A. A. NFאB, heat shock proteins, HSF-1, and inflammation. Cardiovasc. Res., v.69, n.1, p.7-8, 2006.

KUMAR, S.; BOEHM, J.; LEE, J.C. p38 MAP kinases: key signaling molecules as therapeutic targets for inflammatory diseases. Nat. Rev. Drug Discov., v.2, n.9, p.717-726, 2003.

LEVIN, J.I.; CHEN, J.M.; LAAKSO, L.M.; DU, M.; SCHMID, J.; XU, W.; CUMMONS, T.; XU, J.; JIN, G.; BARONE, D.; SKOTNICKI, J.S. Acetylenic TACE inhibitors. Part 3: Thiomorpholine sulfonamide hydroxamates. Bioorg. Med. Chem. Lett., v.16, n.6, p.1605-1609, 2006.

LIMA, L.M.; CASTRO, P.; MACHADO, A.L.; FRAGA, C.M.A.; LUGNIER, C.; MORAES, V.L.G.; BARREIRO, E.J. Synthesis and anti-inflammatory activity of phthalimide derivatives, designed as new thalidomide analogues. Bioorg. Med. Chem., v.10, n.9, p.3067-3073, 2002.

LIMA, L.M.; FRAGA, C.A.M.; KOATZ, V.L.G.; BARREIRO, E.J. Thalidomide and analogs as anti-inflammatory and immunomodulator drug candidates. Anti-inflamm. Antiallergy Agents Med. Chem., v.5, n.1, p.79-95, 2006.
LIN, J.; ZIRING, D.; DESAI, S.; KIM, S.; WONG, M.; KORIN, Y.; BRAUN, J.; REED, E. GJERTSON, D.; SINGH, R.R. TNF $\alpha$ blockade in human diseases: An overview of efficacy and safety. Clin. Immunol., v.126, n.1, p.13-30, 2008.

LIPWORTH, B. Phosphodiesterase-4 inhibitors for asthma and chronic obstructive pulmonary disease. Lancet, v.365, n.9454, p.167-175, 2005.

LIVERTON, N.J.; BUTCHER, J.W.; CLAIBORNE, C.F.; CLAREMON, D.A.; LIBBY, B.E.; NGUYEN, K.T.; PITZENBERGER, S.M.; SELNICK, H.G.; SMITH, G.R.; TEBBEN, A.; VACCA, J.P.; VARGA, S.L.; AGARWAL, L.; DANCHECK, K.; FORSYTH, A.J.; FLETCHER, D.S.; FRANTZ, B.; HANLON, W.A.; HARPER, C.F.; HOFSESS, S.J.; KOSTURA, M.; LIN, J.; LUELL, S.; O’NEILL, E.A.; OREVILLO, C.J.; PANG, M.; PARSONS, J.; ROLANDO, A.; SAHLY, Y.; VISCO, D.M.; O'KEEFE, S.J. Design and synthesis of potent, selective, and orally bioavailable tetrasubstituted imidazole inhibitors of $\mathrm{p} 38$ mitogen-activated protein kinase. J. Med. Chem., v.42, n.12, p.2180-2190, 1999.

MAN, H.W.; CORRAL, L.G.; STIRLING, D.I.; MULLER, G.W. $\alpha$-Fluoro-substituted thalidomide analogues. Bioorg. Med. Chem. Lett., v.13, n.20, p.3415-3417, 2003.

MARRIOTT, J. B.; WESTBY, M.; DAlGLEISH, A. G. Therapeutic potential of TNF- $\alpha$ inhibitors old and new. Drug Discov. Today, v.2, n.7, p.273-282, 1997.

MATTHEWS, S.J.; McCOY, C. Thalidomide: A review of approved and investigational uses. Clin. Ther, v.25, n.2, p.342-395, 2003.

MELCHERT, M.; LIST, A. The thalidomide saga. Int. J. Biochem. Cell Biol., v.39, n.7-8, p.1489-1499, 2007.

MERCURIO, F.; MANNING, A. M. Multiple signals converging on NF-кB. Curr. Opin. Cell Biol., v.11, n.2, p.226-232, 1999.

MOHAN, M.J.; SEATON, T.; MITCHELL, J.; HOWE, A.; BLACKBURN, K.; BURKHART, W.; MOYER, M.; PATEL, I.; WAITT, G.M.; BECHERER, D.; MOSS, M.L.; MILLA, M.E. The tumor necrosis factor alpha converting ezyme (TACE): A unique metalloproteinase with highly defined substrate selectivity. Biochemistry, v.41, n.30, p.9462-9469, 2002. 
MONTALBAN, A.G.; BOMAN, E.; CHANG, C.D.; CEIDE, S.C.; DAHL, R.; DALESANDRO, D.; DELAET, N.G.J.; ERB, E.; ERNST, J.T.; GIBBS, A.; KAHL, J.; KESSLER, L.; LUNDSTRÖM, J.; MILLER, S.; NAKANISHI, H.; ROBERTS, E.; SAIAH, E.; SULLIVAN, R.; WANG, Z.; LARSON, C.J. The design and synthesis of novel $\alpha$-ketoamide-based p38 MAP kinase inhibitors. Bioorg. Med. Chem. Lett., v.18, n.6, p.1772-1777, 2008.

MONTANA, J.G.; BUCKLEY, G.M.; COOPER, N.; DYKE, H.J.; GOWERS, L.; GREGORY, J.P.; HELLEWELL, P.G.; KENDALL, H.J.; LOWE, C.; MAXEY, R.; MIOTLA, J.; NAYLOR, R.J.; RUNCIE, K.A.; TULADHAR, B.; WARNECK, J.B.H. Aryl sulfonamides as selective PDE4 inhibitors. Bioorg. Med. Chem. Lett., v.8, n.19, p.26352640, 1998.

MOREIRA, A.L.; SAMPAIO, E.P.; ZMUIDZINAS, A.; FRINT, P.; SMITH, K.A.; KAPLAN, G. Talidomide exerts its inhibitory action on tumor necrosis factor alpha by enhancing mRNA degradation. J. Exp. Med., v.177, n.6, p.1675-1680, 1993.

MOSS, M. L.; JIN, S. L. C.; MILLA, M. E.; BURKHART, W.; CARTER, H.L.; CHEN, W. J.; DIDSBURY, J. R.; HASSIER, D.; HOFFMAN, C. R.; KOST, T. A.; LAMBERT, M. H.; LEESNITZER, M. A.; McCAULEY, P.; McGEEHAN, G.; MITCHELL, J.; MOYERS, M.; PAHEL, G.; ROCQUE, W.; OVERTON, L. K.; SCHOENEN, F.; SEATON, T.; SU, J.L.; WARNER, J.; WILLARD, D.; BECHERE, J. D. Cloning of a disintegrin metalloproteinase that processes precursor tumor necrosis factor-alpha. Nature, v.385, n.6618, p.733-736, 1997.

MUKHOPADHYAY, S.; HOIDAL, J. R.; MUKHERJEE, T. K. Role of TNF- $\alpha$ in pulmonary pathophysiology. Respir. Res., v.7, n.125, p.1-9, 2006.

MULLER, G.; SHIRE, M.G.; WONG, L.; CORRAL, L.G.; PATTERSON, R.; CHEN, Y.; STIRLING, D. Thalidomide analogs and PDE4 inhibition. Bioorg. Med. Chem. Lett., v.8, n.19, p.2669-2674, 1998.

MULlER, G.; CHEN, R.; HUANG, S.; CORRAL, L.; WONG, L.; PATTERSON, R.; CHEN, Y.; KAPLAN, G.; STIRLING, D. Amino-substituted thalidomide analogs: Potent inhibitors of TNF- $\alpha$ production. Bioorg. Med. Chem. Lett., v.9, n.11, p.1625-1630, 1999.
MUTALIK, V.K.; VENKATESH, K.V. Effect of the MAPK cascade structure, nuclear translocation and regulation of transcription factors on gene expression. BioSystems, v.85, n.2, p.144-157, 2006.

NG, S.S.W.; BROWN, M.; FIGG, W.D. Thalidomide, an antiangiogenic agent with clinical activity in cancer. Biomed. Pharmacother, v.56, n.4, p.194-199, 2002.

PALLADINO, M. A.; BAHJAT, F. R.; THEODORAKIS, E. A.; MOLDAWER, L. L. Anti-TNF- $\alpha$ therapies: the next generation. Nat. Rev. Drug Discov., v.2, n.9, p.736-746, 2003.

PAPPAS, D.A.; BATHON, J.M.; HANICQ, D.; YASOTHAN, U.; KIRKPATRICK, P. Golimumab. Nat. Rev. Drug Discov., v.8, n.9, p.695-696, 2009.

PAUL, A.T.; GOHIL, V.M.; BHUTANI, K.K. Modulating TNF- $\alpha$ signaling with natural products. Drug Discov. Today, v.11, n.15-16, p.725-732, 2006.

PENNICA, D.; NEDWIN, G. E.; HAYFLICK, J. S.; SEEBURG, P. H.; DERYNCK, R.; PALLADINO, M. A.; KOHR, W. J.; AGGARWAL, B. B.; GOEDDEL, D. V. Human tumor necrosis factor: precursor structure, expression and homology to lymphotoxin. Nature, v.312, n.5596, p.724729, 1984.

PETERSON, P.K.; HU, S.; SHENG, W.S.; KRAVITZ, F.H.; MOLITOR, T.W.; CHATTERJEE, D.; CHAO, CC. Thalidomide inhibits tumor necrosis factor-alpha production by lipopolysaccharide and lipoarabinomannanstimulated human microglial cells. J. Infect. Dis., v.172, n.4, p.1137-1140, 1995 .

PIERCE, J.W.; SCHOENLEBER, R.; JESMOK, G.; BEST, J.; MOORE, S.A.; COLLINS, T.; GERRITSEN, M.E. Novel inhibitors of cytokine-induced I $\mathrm{KB} \alpha$ phosphorylation and endothelial cell adhesion molecule expression show antiinflammatory effects in vivo. J. Biol. Chem., v.272, n.34, p.21096-21103, 1997.

PODOLIN, P.L.; CALLAHAN, J.F.; BOLOGNESE, B.J.; LI, Y.H.; CARLSON, K.; DAVIS, T.G.; MELLOR, G.W.; EVANS, C.; ROSHAK, A.K. Attenuation of murine collageninduced arthritis by a novel, potent, selective small molecule inhibitor of IкB kinase 2, TCPA-1 (2-[(aminocarbonyl) amino]-5-(4-fluorophenyl)-3-thiophenecarboxamide), occurs via reduction of proinflammatory cytokines and antigeninduced T cell proliferation. J. Pharmacol. Exp. Ther., v.312, n.1, p.373-381, 2005. 
QIAN, M.; BAI, S.A.; BROGDON, B.; WU, J.T.; LIU, R.Q.; COVINGTON, M.B.; VADDI, K.; NEWTON, R.C.; FOSSLER, M.J.; GARNER, C.E.; DENG, Y.; MADUSKUIE, T.; TRZASKOS, J.; DUAN, J.J.W.; DECICCO, C.P.; CHRIST, D.D. Pharmacokinetics and pharmacodynamics of DPC 333 ((2R)-2-((3R)-3-Amino-3 \{4-[2-methyl-4quinolinyl) methoxy] phenyl $\}$-2-oxopyrrolidinyl)- $N$ hydroxy-4-methylpentanamide)), a potent and selective inhibitor of tumor necrosis factor $\alpha$-converting enzyme in rodents, dogs, chimpanzees and humans. Drug Metab. Dispos., v.35, n.10, p.1916-1925, 2007.

ROUX, P.P.; BLENIS, J. ERK and p38 MAPK-activated protein kinases: a family of protein kinases with diverse biological functions. Microbiol. Mol. Biol. Rev., v.68, n.2, p.320-344, 2004.

SACK, M.N. Tumor necrosis factor- $\alpha$ in cardiovascular biology and the potential role for anti-tumor necrosis factor- $\alpha$ therapy in heart disease. Pharmacol. Ther., v.94, n.1-2, p.123-135, 2002.

SAMPAIO, E. P.; SARNO, E. N.; GALILLY, R.; COHN, Z.A.; KAPLAN, G. Thalidomide selectively inhibits tumor necrosis factor alpha production by stimulated human monocytes. J. Exp. Med., v.173, n.3, p.699-703, 1991.

SAMPAIO, E. P.; HERNANDEZ, M. O.; CARVALHO, D. S.; SARNO, E. N. Management of erythema nodosum leprosum by thalidomide: thalidomide analogues inhibit M. leprae-induced TNF production in vitro. Biomed. Pharmacother, v.56, n.1, p.13-19, 2002.

SAMPAIO, E.P.; CARVALHO, D.S.; NERY, J.A.C.; LOPES, U.G.; SARNO, E.N. Thalidomide: An overview of its pharmacological mechanisms of action. Anti-Inflamm. Anti-Allergy Agents Med. Chem., v.5, n.1, p.71-77, 2006.

SHIMIZU, S.; YAMADA, Y.; OKUNO, M.; OHNISHI, H.; OSAWA, Y.; SEISHIMA, M.; MORIWAKI, H. Liver injury induced by lipopolysaccharide is mediated by TNFR-1 but not by TNFR-2 or Fas in mice. Hepatol. Res., v.31, n.3, p.136-142, 2005.

SIROHI, B.; POWLES, R. Multiple Myeloma. Lancet, v.363, n.9412, p.875-887, 2004.

SMITH, S.; SKERRETT, S.J.; CHI, E.Y.; JONAS, M.; MOHLER, K.; WILSON, C.B. The locus of Tumor Necrosis Factor alpha action in lung inflammation. Am. J. Respir. Cell Mol. Biol., v.19, n.6, p.881-891, 1998.
STEINWURZ, F. Experiência clínica com o uso de Infliximab em 44 portadores de doença de Crohn. Arq. Gastroenterol., v.40, n.3, p.198-200, 2003.

SURYAPRASAD, A.G.; PRINDIVILLE, T. The biology of TNF blockade. Autoimmun. Rev., v.2, n.6, p.346-357, 2003.

TARTAGLIA, L. A.; PENICCA, D.; GOEDDEL, D. V. Ligand passing: The 75-kDa Tumor necrosis factor (TNF) receptor recruits TNF for signaling by the $55-\mathrm{kDa}$ TNF receptor. $J$. Biol. Chem., v.268, n.25, p.18542-18548, 1993.

TAYLOR, P.C. Pharmacology of TNF blockade in rheumatoid arthritis and other chronic inflammatory diseases. Curr. Opin. Pharmacol. v.10, n.3, p.308-315, 2010.

TEO, S.K.; STIRLING, D.I.; ZELDIS, J.B. Thalidomide as a novel therapeutic agent: new uses for an old product. Drug Discov. Today, v.10, n.2, p.107-113, 2005.

TRACEY, D.; KLARESKONG, L.; SASSO, E.H.; SALFELD, J.G.; TAK, P.P. Tumor necrosis factor antagonist mechanisms of action: a comprehensive review. Pharmacol. Ther., v.117, n.2, p.244-279, 2008.

TRIFILIEFF, A.; WALKER, C.; KELLER, T.; KOTTIRSCH, G.; NEUMANN, U. Pharmacological profile of PKF242484 and PKF241-466, novel dual inhibitors of TNF- $\alpha$ converting enzyme and matrix metalloproteinases, in models of airway inflammation. Br. J. Pharmacol., v.135, n. 7, p.1655-1664, 2002.

VOORHEES, P.M.; ORLOWSKI, R.Z. The proteasome and proteasome inhibitors in cancer therapy. Annu. Rev. Pharmacol. Toxicol., v.46, p.189-313, 2006.

WEN, D.; NONG, Y.; MORGAN, J.G.; GANGURDE, P.; BIELECKI, A.; DASILVA, J. KEAVENEY, M.; CHENG, H.; FRASER, C.; SCHOPF, L.; HEPPERLE, M.; HARRIMAN, G.; JAFFEE, B.D.; OCAIN, T.D.; XU, Y. A selective small molecule I $\kappa$ B kinase $\beta$ inhibitor blocks nuclear factor $\kappa B$-mediated inflammatory responses in human fibroblast-like synoviocytes, chondrocytes, and mast cells. J. Pharmacol. Exp. Ther., v.317, n.3, p.9891001, 2006.

YAMAMOTO, S.; SUGAHARA, S.; IKEDA, K.; SHIMIZU, $\mathrm{Y}$. Amelioration of collagen-induced arthritis in mice by a novel phosphodiesterase 7 and 4 dual inhibitor, YM393059. Eur. J. Pharmacol., v.559, n.2-3, p.219-226, 2007. 
ZHANG, J.G.; HEPBURN, L.; CRUZ, G.; BORMAN, R.A.; CLARK, K.L. The role of adenosine $\mathrm{A} 2 \mathrm{~A}$ and $\mathrm{A} 2 \mathrm{~B}$ receptors in the regulation of TNF- $\alpha$ production by human monocytes. Biochem. Pharmacol., v.69, n.6, p.883-889, 2005.

ZHANG, J.; SHEN, B.; LIN, A. Novel strategies for inhibition of the p38 MAPK pathway. Trends Pharmacol. Sci., v.28, n.6, p.286-295, 2007.
ZUANY-AMORIN, C.; HASTEWELL, J.; WALKER, C. Tolllike receptors as potential targets for multiple diseases. Nat. Rev. Drug Discov., v.1, n.10, p.797-807, 2002.

Received for publication on $8^{\text {th }}$ July 2010 Accepted for publication on $25^{\text {th }}$ May 2011 